Leen Engelen and

Marjan Sterckx

\section{An ephemeral open-air sculpture museum: ten temporary monuments for the festive return of the Belgian royal family to Brussels, November 1918}

Immediately after the First World War and continuing well into the 1920s and 1930s, monuments commemorating the war were erected all over Europe. Although the concept of commemorating war through monuments long predates the First World War, no other war gave rise to such a large number of memorials. ${ }^{1}$ In formerly occupied territories such as Belgium and northern France, the need to express grief as well as gratitude, which had been suppressed by the occupying regime for over four years, appeared as soon as the Armistice was signed. ${ }^{2}$ Ideas for monuments surfaced instantaneously and enthusiastically on the national and municipal level. Plans were proposed by formal and informal local associations, such as parishes, labour unions and sports clubs, but not all of these intentions materialized. Many did so only after a long time. ${ }^{3}$

This article takes as its subject a phenomenon slightly predating the large-scale post-war statuomanie. It presents a case study of an exceptional series of ten ${ }^{4}$ temporary monuments commissioned by the city of Brussels on the occasion of the festive return of the royal family to the Belgian capital on 22 November 1918.5 These very first structures of First World War commemoration were placed in the city centre as part of the festive decorations and were made in stucco. They were thus fragile and only stayed in Brussels's public space for a short while. Nevertheless, the plaster monuments left a paper trail: the research presented here is based on newspaper articles, picture postcards, snapshots, newsreels and archival sources. The latter are scarce, because decisions were made hastily, and improvised procedures were used to speed up the process. Conceived as they were in the short transitional period between the war and its aftermath, one can ask whether these chaotic conditions and the preconceived temporality of the monuments prompted experimentation and innovation and heralded an altogether new artistic élan.

This article presents, for the first time, a full account of the monuments and their authors, and considers the genesis, reception and afterlife of the sculpture series. We then consider two contextual factors: the concept of the city as a democratic open-air sculpture museum, already much in vogue in Brussels in the Belle Époque, and the existing tradition of temporary sculpture within the cityscape, notably in the context of nineteenth-century patriotic festivities. We believe both aspects - along with sculptors' feelings of patriotism, generosity and possible opportunism - contributed to the unique and speedy initiative taken in Brussels in 1918 to realize a parcours of ephemeral statues. Both angles will be framed by the specificity of the immediate post-war era. 


\section{The context of the project}

The series of temporary monuments was part of the decorative arrangements ordered by the city council to commemorate the return of King Albert and the royal family to the Belgian capital after four years of exile. Throughout the war, the king had stayed as close as possible to his troops at the front. He resided in La Panne, a small coastal town in the last corner of free Belgium near the French border. Queen Elisabeth stayed with him for most of the time while committing herself to the Red Cross hospital L'Océan. Their return to the capital took place eleven days after the signing of the Armistice on 11 November 1918, and it was this day, 22 November, that was considered the real end of the occupation and marked the beginning of the post-war era in Belgium. ${ }^{6}$ The royal family and some 6,0oo Belgian and Allied troops were welcomed by a huge crowd. The manifold contemporary sources documenting the day show that the atmosphere was festive. There was marching music, and dense throngs of people cheered. People climbed on to lamp posts and hung out of windows; there were garlands everywhere and 'thousands and thousands of flags'? The press was very enthusiastic about the city's appearance - one reporter even called it 'the most beautiful city in the world'. 8 Next to the lavish decoration and the military parade, the public monuments in stucco were an important attraction.

The monuments sited together formed a kind of trajectory through the city, intersecting - though not coinciding with - the route of the royal procession. ${ }^{9}$ The reports of city council meetings clearly list ten monuments with their locations. ${ }^{10}$ Nine of these were in the northern half of Brussels's pentagon, roughly in the area between the Royal Park and the Grand-Place. They were located on and in some of the city's most central and visible squares and parks, mostly sites with stunning backgrounds or city vistas (fig. 1). The oldest and most established sculptors, born in the 1850 os and 1860 , occupied the most prestigious sites, whereas the others were decorated by a slightly younger generation, all in their forties.

Very little is known about the exact commission, its conditions and the choice of the artists. In the newspaper Le Matin, it simply reads: 'Monumental groups in stucco were ordered from sculptors. ${ }^{11}$ In the turmoil at the end of the occupation and the haste with which the liberation festivities had to be prepared, the usual commission procedures that could last years were not followed, and the official paper trail of the monuments' genesis is therefore very sparse. As late as mid-November 1918, the press reported that the city council had voted for a remarkably high budget of 500,000 francs to decorate the city, including the monuments. ${ }^{12}$ The project was to be supervised by François Auguste Malfait (1872-1955), the official city architect from 1917 to 1942 , who, it seems, went on to put extraordinary effort into the enterprise.

Malfait was assisted in decorating the city by Jean Delescluze (1871-1947), the master decorator of Brussels's prestigious Théâtre Royal de la Monnaie, and by a certain Dubosch. ${ }^{13}$ Presumably, Malfait also played a pivotal role in the architectural aspect of the 1918 monument series. Monuments were usually 


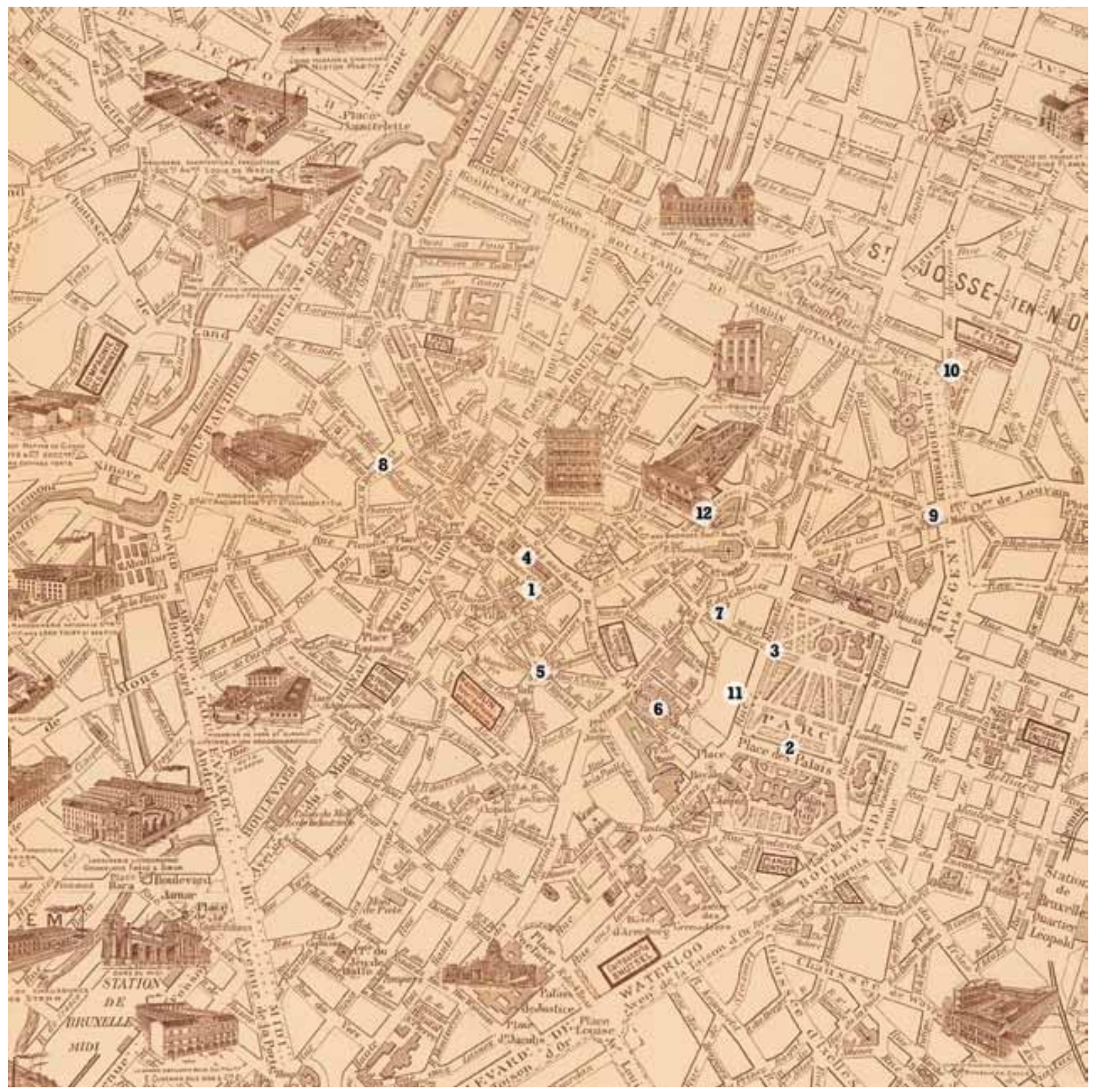

1 La Brabançonne, Charles Samuel, 1918

2 À notre grand roi et notre vaillante armée, Jules Lagae, 1918 3 À nos héros (Yser), Philippe Wolfers, 1918

4 À Miss Edith Cavell. Hommage à l'Angleterre, Jacques Marin, 1918 5 À nos soldats morts pour la Patrie, Louis Mascré, 1918 6 Allégorie de la Paix, Léandre Grandmoulin, 1918 7 À nos blessés, Joseph François Van Hamme, 1918
8 Hommage à l'Italie, Georges Vandevoorde, 1918

9 Elle arrêta le flot, La Belgique arrêtant le flot germanique (La vague), Marquis de Pouilly, 1918

10 La Belgique reconquise, Guillaume Charlier, 1917

11 Comte Augustin-Daniel Belliard, Guillaume Geefs, 1836, with

decorations by Jean Delescluze, 1918

12 Premises of the Compagnie des Bronzes
1. Nouveau Plan de Bruxelles Industriel, 1910 (annotation by the authors). Mapping by David Verdeure collaborations between sculptors and architects. The latter often designed the plinth and decided on the architectural setting of the sculpture. In this case, the names of any other architects involved in the project have not emerged. Moreover, it is known that Malfait was to design the provisional cenotaph erected in the Brussels Royal Park in July 1919. ${ }^{14}$ During the interwar period, in his capacity as city architect, Malfait would also be involved in designing the plans of several public monuments in Brussels, such as the fountain Naiad (1923) 
in the rue Baron Horta, together with the sculptor Jacques Marin (one of the sculptors of the 1918 series), and the Monument to the French Unknown Soldier Killed on Belgian Soil during the 1914-18 War (1927), together with the sculptors Mathieu Desmaré, Jean Rombeaux and Ernest Salu. ${ }^{15}$

According to the newspaper Le Soir, the sculptors completed their plaster projects in only a fortnight, a truly impressive feat, almost impossible even, in view of the fact that the casting of such large models takes considerable time. ${ }^{16}$ The speed with which the works were realized is even more remarkable because several sculptures were ready and in place a few days before the deadline. ${ }^{17}$ Le Soir spoke of 'improvised' monuments, ${ }^{18}$ but it seems - and this is only logical - that many of the artists involved were inventive in the reuse and creative adaptation of existing models or designs. Alternatively, they might already have prepared their contribution to post-war commemorations during the war. The Brussels writer, journalist and art critic Sander Pierron (1872-1945), who specialized in sculpture, formulated it thus: 'A not quite so spontaneous flowering, for if some of these works were realized as quickly as the victory of our armies was confirmed, others had been long conceived and executed in the silence of the workshop.' ${ }^{19}$ He spoke of 'sketches' that would have to be reworked or fine-tuned when finished in marble or bronze. Some sculptors would also recycle parts of their 1918 monuments in later works.

All of the sculptors involved seemed eager to participate in the project. Several of them were established, had already won important prizes, like the Prix de Rome or the Prix Godecharle, and had studied in Paris and Italy. Others did not yet have very successful careers. Most of the sculptors knew each other well and belonged to the same networks. They had the same masters and took part in the same exhibitions and Brussels art unions, such as the Cercle Artistique et Littéraire and the more progressive L'Essor and Pour l'Art. Some were also friends. The majority were from Brussels or had trained at the Brussels Academy, most of them with the influential teacher Charles Van der Stappen (1843-1910). The latter was himself influenced by sojourns in Paris and Italy in the 1860 s and 1870 s, and by his contacts with contemporary writers, such as Camille Lemonnier and Edmond Picard.

The 1918 project provided the sculptors not only with an opportunity to show generosity and patriotism and sometimes a means to express personal grief, but also the chance to obtain visibility and prestige after a difficult financial period. This was true for many artists, sculptors in particular. Whereas salon paintings were still exhibited in Brussels during the war, this was significantly less the case for the much more expensive discipline of sculpture. From 1916 onwards, only some small plasters were exhibited in Brussels galleries. ${ }^{20}$

It appears that no formal guidelines or templates for the temporary monuments were provided. The works varied remarkably in style, genre, height and format, and featured bas-reliefs and busts as well as full-length statues. The all-figurative statues represented personalities as well as small realist groups (the troops, the wounded or grieving women) and semi-nude historical and abstract allegories (e.g. Lady Belgium - sometimes called La 
Brabançonne - with different qualities, triumphant or grieving). Moreover, the statues were adorned with patriotic attributes such as flags, lions, Adrian helmets and laurel wreaths in various combinations. The monuments paid homage to a variety of causes in the military sphere: to the heroism of the Belgian soldiers who had died for their country, the wounded soldiers, King Albert I, the British nurse Edith Cavell executed in Brussels, the Allies

2. Charles Samuel, $\mathrm{La}$ Brabançonne, 1918 (photo: Brussels City Archive (Guerre 1914-1918 [Monuments provisoires érigés dans la Ville de Bruxelles (en 1918 ou 1919) en reconnaissance aux soldats et victimes de la guerre], C-1882)

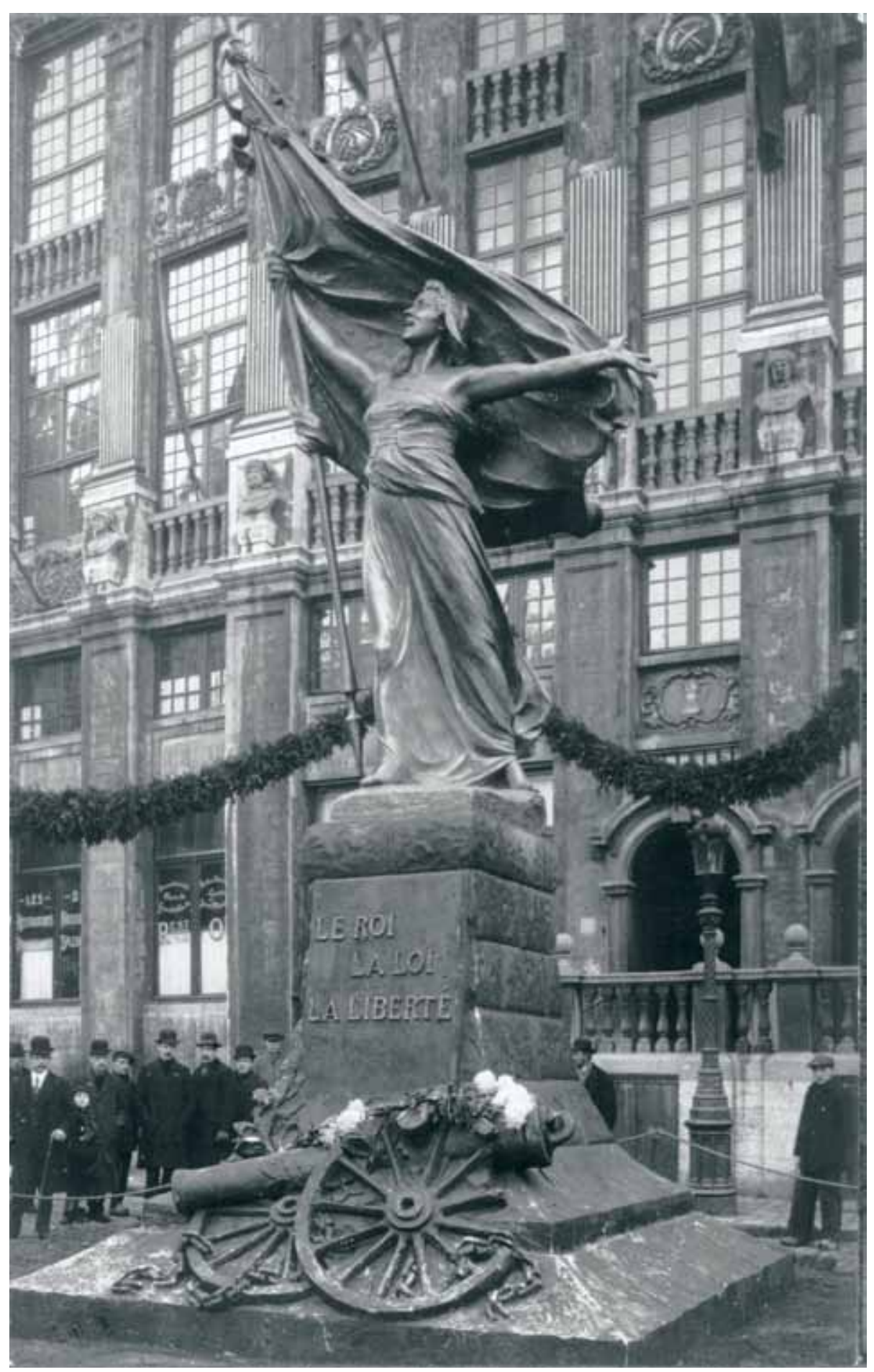

325 | Engelen and Sterckx: An ephemeral open-air sculpture museum 
(monuments dedicated to France, Italy, England and the United States) and more abstract values such as liberty, law and peace. An article in the press suggests that the choice of topics was steered by the city architect Malfait, who explicitly solicited monuments dedicated to Italy and the United States. ${ }^{21}$ By honouring the Allies, international diplomatic concerns were taken into account. This was much less the case with internal sensibilities regarding the suffering of different groups in the civilian population..$^{22}$

\section{The appearance of the monuments}

Photographs and picture postcards, as well as contemporary press reports, provide valuable visual and textual accounts of the temporary monuments after their disappearance from public space. The Catholic newspaper Le Soir briefly introduced five of the most frequently mentioned monuments to its readers as follows:

On the Grand Place, the Brabançonne by Samuel entices, in a beautiful movement, the people seduced by her song. M. Jacques Marin remembers the martyrdom of Miss Cavell, symbolized by the image of a woman in chains, followed by a group of lamenting women. In Place Saint-Jean, M. Mascré invites us to think about the dead, and represents a soldier lying down, supported by a nurse, by la Patrie herself. In the Park, M. Wolfers marries the united races of Flanders and Wallonia in a beautiful composition. And of all these monuments improvised for the street festivities, one of the most poignant is that of a French artist, Marquis de Pouilly, who erected on the place Surlet de Chokier, under a military porch, Lady Belgium trembling, energetically pushing away the invading enemy. In this way, the artists, the people, are singing a poem of enthusiasm, a hymn of victory. ${ }^{23}$

La Brabançonne (fig. 2) on the Grand-Place (fig. 1, no. 1) appears to be the most mentioned of the 1918 series. It was actually only a larger and more detailed edition $(8 \mathrm{~m} / 26 \mathrm{ft})$ of a statuette $(47 \mathrm{~cm} / 1.5 \mathrm{ft})$ that Charles Samuel $(1862-1938)$ had already cast in bronze, in multiple copies, through the Brussels Compagnie des Bronzes (fig. 1, no. 12) in June 1916. ${ }^{24}$ Samuel also continued to exhibit in Brussels during the war. ${ }^{25}$ That the author requested the statuette to be re-issued again in November 1918 might indicate that he expected a rise in demand. Despite noble intentions, commemoration remained a business after all. La Brabançonne is a victorious female figure with her muscular right arm firmly holding up the flag and the left stretched out. She wears a long clinging robe, with one shoulder bare. Holding her head high, she glares into the distance. Her mouth is opened, as if enthusiastically chanting the triumphant 'le roi, la loi, la liberté', as inscribed on the plinth decorated with a cannon and broken chains in bas-relief. According to Sander Pierron, the figure that he interprets as La délivrance (Liberation) lacks elegance; he calls her vehemence 'plebeian'. ${ }^{26}$ In her pose and determination, Samuel's Brabançonne is 


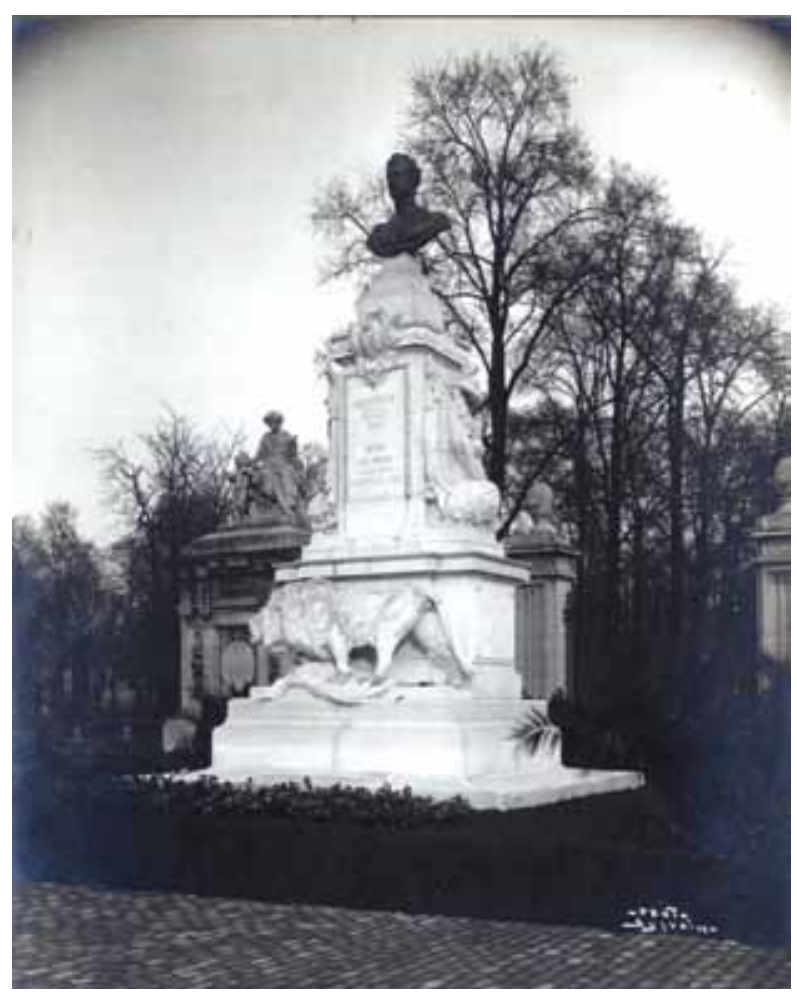

reminiscent of the female protagonists in Eugène Delacroix's painting La Liberté guidant le peuple or François Rude's more challenging haut-relief La Marseillaise. Both are romantic, political works from the 1830 s (also the era of Belgium's revolution and nationhood) and related to revolution and the threat of foreign powers.

Charles Samuel was trained at the Brussels Academy by, among others, Charles Van der Stappen. He was a member of the Cercle Artistique et Littéraire and of L'Essor. He did not succeed in obtaining the Prix de Rome or Prix Godecharle, but was much honoured. Before the war, Samuel had already completed numerous successful ornamental and funerary sculptures, portraits (e.g. the marble bust of Queen Elisabeth of Belgium, 1910, the counterpart of Jules Lagae's bust of King Albert) and monuments within and beyond Brussels. Examples include his monument commemorating the novel Tijl Uilenspiegel and its author Charles de Coster (1894), and the memorial

3. Jules Lagae, $\grave{A}$ notre grand roi et notre vaillante armée, 1918 (photo: Library Ghent University) to the victims of the wreck of the first Belgian school ship De Smet de Naeyer (1910-12) - a recent tragedy. ${ }^{27}$

A contemporary of Samuel, Jules Lagae (1862-1931), was responsible for perhaps the next most cited work, the bust of King Albert, dressed in antique style and wearing a laurel crown, placed at the Place des Palais facing the Royal Palace (fig. 1, no. 2). The bust was placed atop a high pedestal, which was decorated prominently at the base by a lion symbolizing Belgium crushing the German eagle. ${ }^{28}$ Entitled À notre grand roi et notre vaillante armée (To Our Great King and Our Brave Army), the inscription on the plinth makes reference to the Roman Fabius Maximus, who wore Hannibal down by avoiding direct engagement: 'Tu Maximus ille est unus qui nobis cunctando restituis rem' ('You there are that Maximus who alone, by hesitation, are the restorer of our state') (fig. 3).

As for Lagae, the war had not treated him well. Commissions were few and far between, and he mainly manufactured medals and busts for friends and acquaintances. When completing his statue of King Albert, he was still mourning the loss of his oldest son Raymond, who had died on the battlefield in October 1918. ${ }^{29}$ His choice to make a bust of King Albert is not surprising. Not only were busts one of his specialities, but he had already made a similar bust of Albert in 1907. On this occasion, he had been invited to the Royal Palace for the sittings. The two men had already met in 1899 when Prince Albert visited Lagae's workplace. ${ }^{30}$ The lion at the foot of the pedestal was not a new work either. Lagae had already completed several lions, including a very similar one for the de Smet de Naeyer bridge in Ostend (1907) (fig. 4). ${ }^{31}$

Lagae had been a student and assistant of Van der Stappen too. He also 


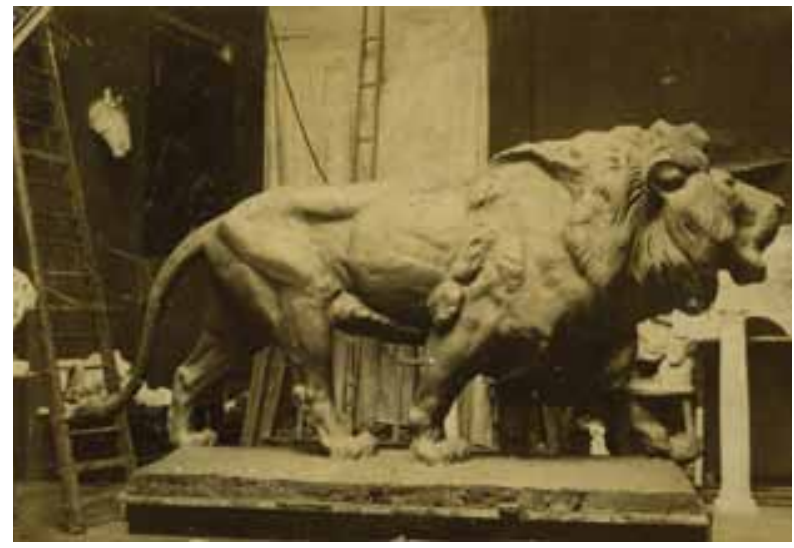

frequented the studios of sculptors Julien Dillens (1849-1904), to whom he made the monument in Brussels in 1907, and Jef Lambeaux (1852-1908), infamous for his monumental marble realist relief Passions humaines (1886-99) in its Brussels pavilion designed by Victor Horta. Lagae was accepted as a member of the literary circle La Jeune Belgique and of L'Essor, where he exhibited, as he did on many other occasions, such as at La Libre Esthétique and the idealist art union Pour l'Art. After winning the Prix de Rome in 1888, he worked abroad for several years and gained international

4. Jules Lagae, lion for de Smet de Naeyerlaan Ostend, 1906 (photo: Collection John Goddeeris) fame, receiving many prizes and public sculpture commissions in Belgium and abroad. Like Samuel, Lagae also obtained a gold medal at the Paris World Fair of 1900, and both participated in the monumental sculptural decoration of the Brussels Botanic Garden. In 1906 Lagae was invited, together with Auguste Rodin, to become a member of the Berlin Academy. He remained in Buenos Aires for the unveiling of his huge Monumento a los dos congresos (1909-14) at the outbreak of the First World War. In the 1920s and 1930s, Lagae authored several war memorials in Belgium and abroad. ${ }^{32}$

In the Parc Royal around the corner (fig. 1, no. 3) was placed on a massive plinth the somewhat unexpected statue entitled À nos héros (To Our Heroes), also known as Yser (fig. 5). It features two robust nude women (in 1918 read as representing Flanders and Wallonia), stretching their upper bodies and arms forward and presenting laurel crowns. They barely keep their balance, each standing on tiptoe on one leg only. The rightmost woman has her right knee bent upwards, whereas the leftmost woman stretches her left leg backwards. This statue also had earlier roots. Philippe Wolfers (1858-1929) based the statue on a freer and more exuberant esquisse that he had already designed in 1912, entitled Les cerceaux or sometimes Les couronnes. Five bronze exemplars were made of it, one of which was sold at the 1912 salon of the Cercle Pour l'Art. The style of the esquisse is somewhat reminiscent of Rik Wouters's (1882-1916) work. In 1918 Wolfers adapted the former design to the new circumstances by slightly altering the position of legs, arms and heads, by making the figures more muscular and by adding a third laurel wreath. Moreover, a modest ship's hull ornament was added in front, and matter was kept between the figures' legs, both creating a more stable effect and a more monumental appeal. Next to the large version in stucco after this new design, Wolfers made one small marble and three bronze statuettes, the first of which was offered to the Belgian war hero General Jacques de Dixmude. ${ }^{33}$

In November 1918 Wolfers donated his monument to the city. The fact that the generosity of this gesture received considerable attention in the press might imply that the other sculptors were remunerated for their work. Around the time of its removal, in late January 1919, Wolfers offered to execute the statue in marble at his own expense, keen to keep it in a public space. ${ }^{34}$ However, the ephemeral À nos héros would remain Wolfers's first and last 
public sculpture. ${ }^{35}$ With his father and two brothers, Philippe Wolfers steered the renowned Wolfers jewellery firm in Brussels as its artistic director from 1892 until his death. He was trained by his father Louis, a master goldsmith, and at the Brussels Academy. Only from around 1905 did Philippe Wolfers, who himself trained the young Charles Samuel (their families were friendly), focus on sculpture, producing statuettes and more monumental works, mostly female nudes, of which his 1918 statue is a typical example.

At the Emplacement de la Grande-Boucherie near the Grand-Place behind

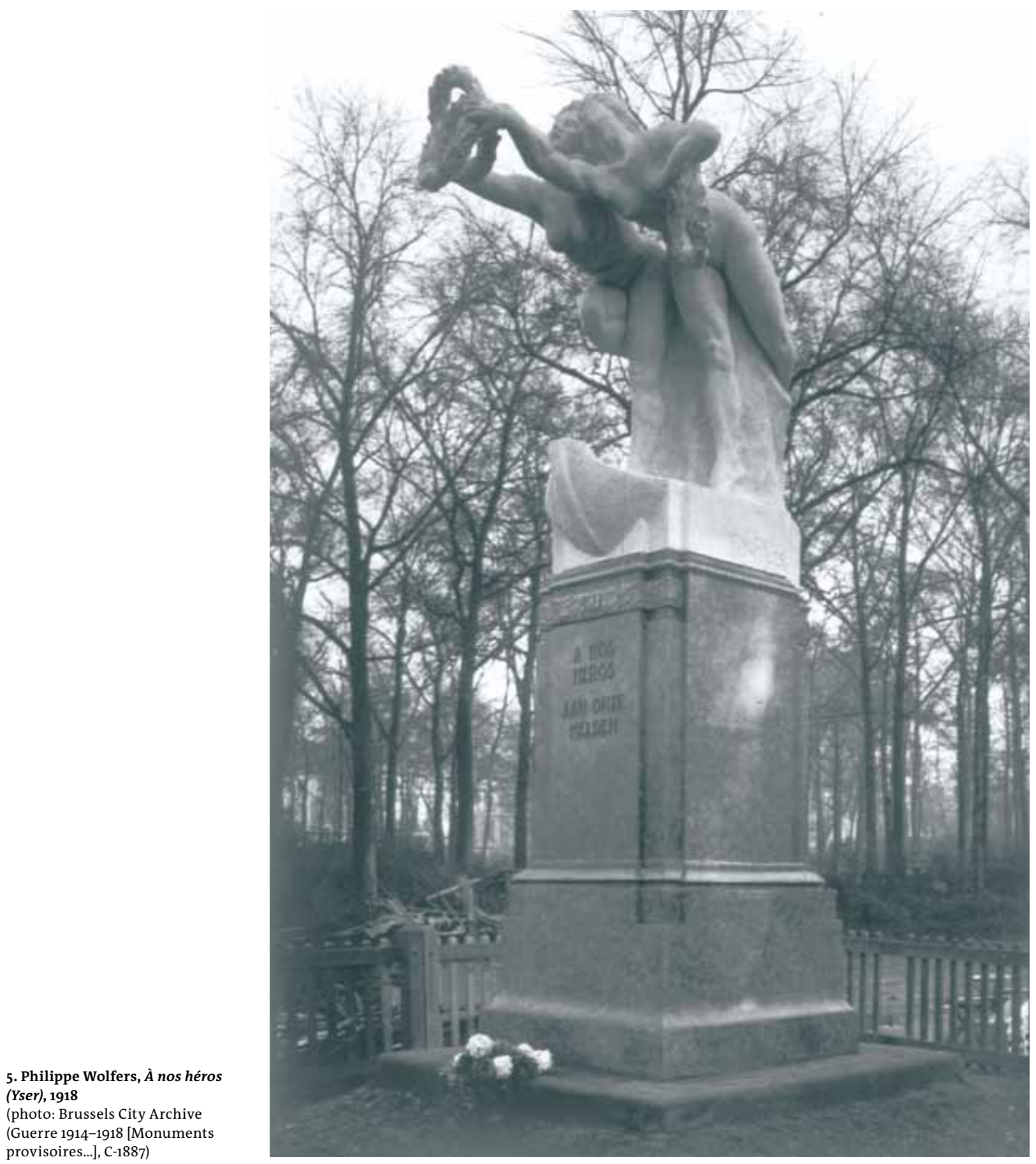


6. Jacques Marin, $\grave{A}$ Miss Edith Cavell. Hommage à l'Angleterre, 1918 , picture postcard,

$13.5 \times 8.7 \mathrm{~cm}$

(photo: collection of the authors)

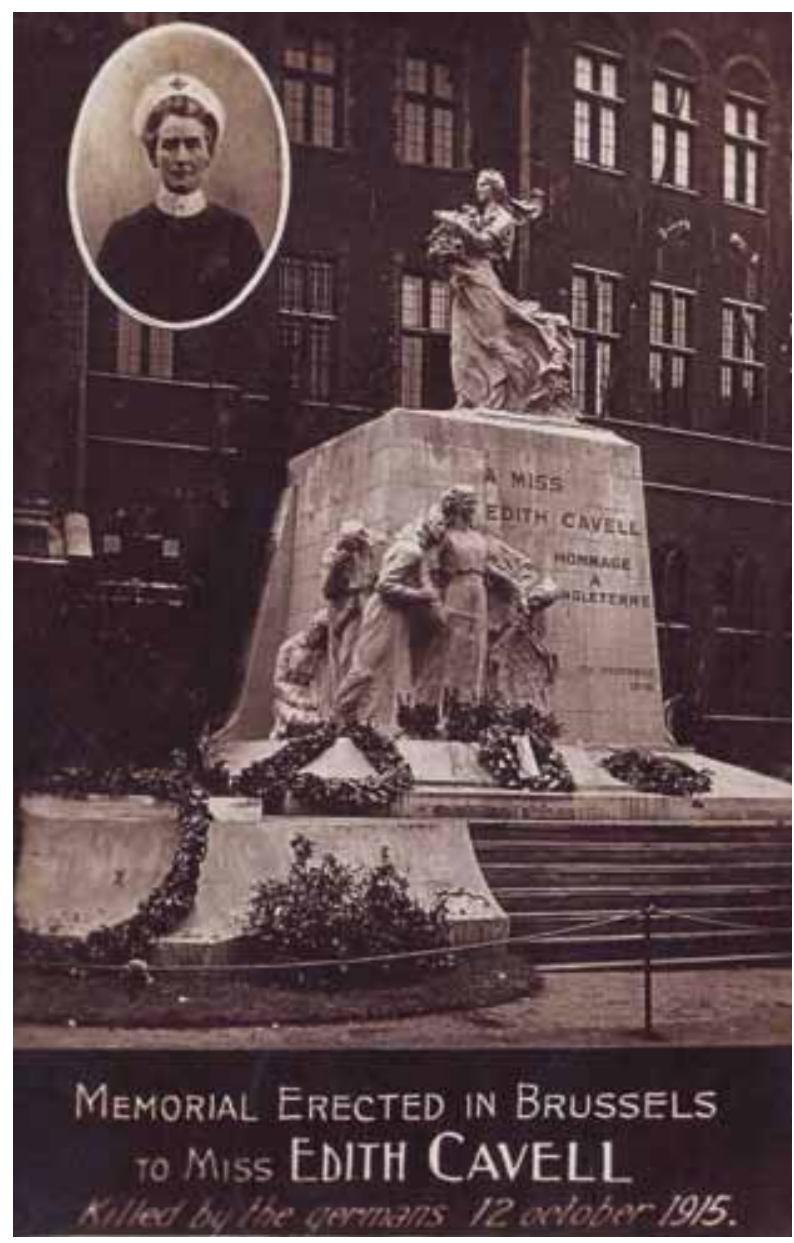

the Broodhuis (fig. 1, no. 4) was erected a massive temporary monument in honour of Edith Cavell and England by Jacques Marin (1877-1950) (fig. 6). After being sentenced to death for treason by German court-martial, the British-born nurse Edith Cavell was executed at the national shooting range in Brussels on 12 October 1915. Her death caused international outrage and gave rise to an immediate cult of commemoration. This cult was naturally much more lively in unoccupied regions, but in Belgium it did not go unnoticed either. By November 1915 a Belgian newspaper published in London had already informed its readers of the plan to erect a monument at the national shooting range as soon as the Germans left. ${ }^{36}$ By November 1918 forty people (including Cavell and another woman, the Belgian spy Gabrielle Petit) had been executed at the shooting range. It comes as no surprise, then, that one of the temporary monuments was dedicated to Cavell. She is represented as a nurse in chains, followed and supported by lamenting nurses, herself standing proudly erect at the foot of a second large pedestal with the inscription 'A Miss Edith Cavell. Hommage à l'Angleterre. 22 November 1918'. On top of this pedestal is placed a striding female allegory (possibly Glory or Lady Belgium), with blowing hair and dress, her arms filled with flowers.

Its sculptor, Jacques Marin, was another pupil of Van der Stappen at the Brussels Academy. He won the Prix Godecharle in 1897, came second (twice) for the Prix de Rome, and exhibited at salons, world fairs and the art unions Le Sillon and the Cercle Artistique et Littéraire. In 1906 his participation was reviewed by Sander Pierron, who compared him to the French Etienne Falconet and to Jef Lambeaux. Like several other Belgian sculptors at the time, such as Samuel and Wolfers, he also created chryselephantine sculpture. During the war, Marin was director at the Academy of Tirlemont, and afterwards, from 1919 until 1947, he would become a teacher and later director at the Brussels Academy. He would also realize several permanent war memorials, mostly in the Walloon region. ${ }^{37}$

Louis Mascré (1871-1927) was the artist responsible for the statue $A \dot{A}$ nos soldats morts pour la Patrie (fig. 7) at the Place Saint-Jean (fig. 1, no. 5). This monument follows a scheme similar to the Cavell monument: a sentimental, realist group on a lower pedestal - here two women (his mother and fiancée?) lamenting over a dying soldier in uniform - is surmounted by an idealist allegorical female figure. The latter, rather stiff figure (la Patrie, Glory or Fame) holds a flag in her left hand 


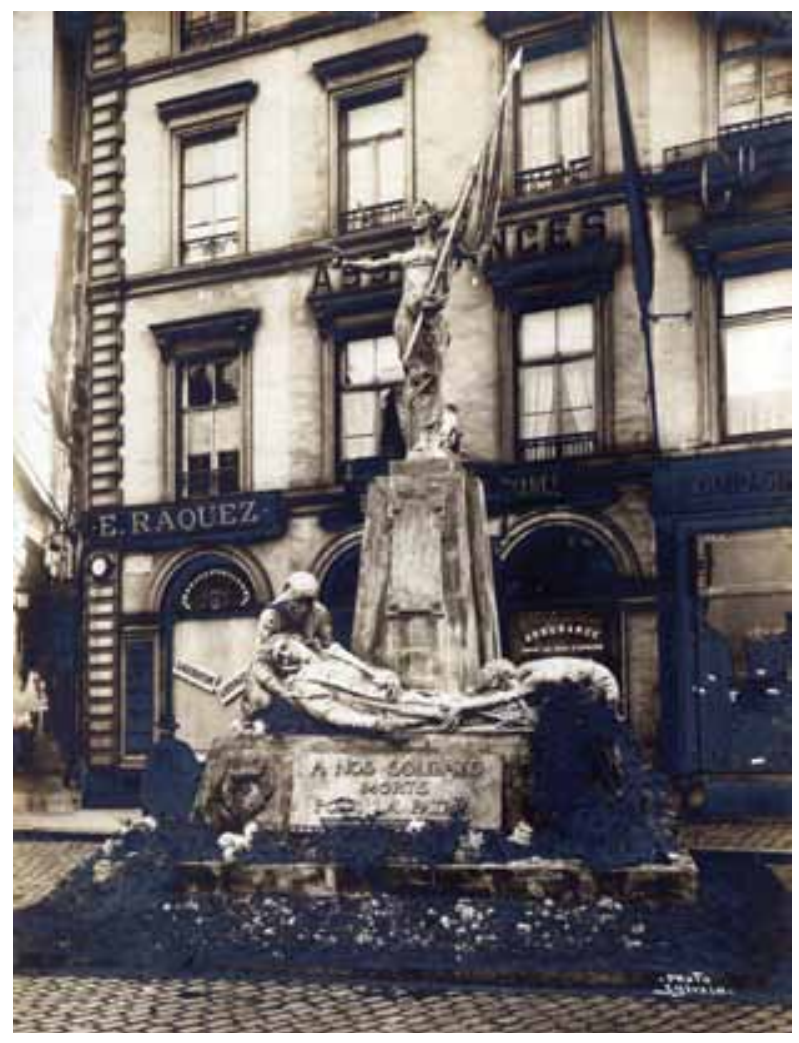

and a laurel wreath in her right. The group below is reminiscent of the Christian archetype of the descent of Christ from the cross with Mary and Mary Magdalen. Mascré was another pupil of Van der Stappen in Brussels. Like Marin, he showed his work at Le Sillon and at several other salons and world fairs. Mascré's work was criticized by the influential Octave Maus (1856-1919) in L'Art Moderne in 1900. After the war, Mascré completed another war memorial (Monument aux Fusillés, 1926 , Sambreville), but he generally specialized in portraiture, for example of Emile Verhaeren and Edmond Picard..$^{38}$

Léandre Grandmoulin (1873-1957) authored the Allégorie de la Paix (fig. 8) at the Mont-des-Arts that links Brussels's downtown (the historical centre with the Grand-Place) to the upper town (with the Royal Palace and Park, and the Musées Royaux de l'État) (fig. 1, no. 6). It is a modest group with three figures. The central figure is a classic, striding female allegory in a drapé-mouillé dress revealing her robust body, with a coat blowing behind her.

7. Louis Mascré, Á nos soldats morts pour la Patrie, 1918 (photo: Library Ghent University)
She presents a flower from her left hand and is flanked by two putti that reminded Sander Pierron of Artus Quellinus or Duquesnoy. ${ }^{39}$ One is sitting with a book, globe and compass, and flowers behind him, representing the arts and sciences; another stands upright with grain, representing agriculture. The inscriptions read 'Pax' and 'Aux États-Unis d'Amérique' (to the United States of America).

Grandmoulin exhibited his plaster La Paix again at the Cercle Artistique et Littéraire de Bruxelles in 1920, as well as in Paris in $1921 .{ }^{\circ} \mathrm{He}$ recycled the female figure from the pre-war, large-scale, neo-baroque Monument au Baron Lambermont that he completed in collaboration with the architect Frans Van Holder in Antwerp, and that was unveiled in August 1912 in the presence of King Albert and Queen Elisabeth. ${ }^{41}$ The 1918 figure of Peace is identical (or almost) to the central bronze figure in the Lambermont monument, where it represents Progress or Expansion. It is there flanked by a young man standing nude and symbolizing Commerce, as well as a nude woman sitting with flowers and a wheel gear, symbolizing Industry. The stone front of this monument is formed by the bow of a ship, which might have inspired Wolfers for his similar addition to his Les cerceaux.

In the 1890s, while in military service, Grandmoulin was a student at the Brussels Academy with - again - Van der Stappen as a teacher. He became an apprentice of Victor Rousseau (1865-1954), Égide Rombaux (1865-1942) and Constantin Meunier (1831-1905). The latter stimulated his interest in social realism to such an extent that La Fédération Artistique and L'Art Moderne criticized Grandmoulin for following Meunier too much. ${ }^{42} \mathrm{He}$ was a member 
8. Léandre Grandmoulin, Allégorie de la Paix, 1918 (photo: Library Ghent University) of the artists' Cercle Labeur, where he exhibited, among other works, a sower and a haymaker (1900), as well as a bust of Sander Pierron (1904). During the war, Grandmoulin continued to exhibit in Brussels at the Salon des Indépendants as well as the Salon d'Automne. Pour l'Art also showed his work. He finished several public monuments in the first half of the twentieth century, such as a war memorial in Uccle, Brussels (1925).

Joseph François Van Hamme (1878-?) was the author of À nos blessés (fig. 9) in the street then called Rue du Parchemin (fig. 1, no. 7). Three figures occupy a simple plinth. A nude young man is carefully supporting a nude, wounded adolescent, unable to walk on his left leg. Behind them is a larger classical female figure with wings, in a long classical dress but with her arms and one breast bare, presumably a personification of Victory or Glory. With her right arm she touches the wounded man. Her left hand is raised, as if to hold a (missing) flag or torch. Maybe this figure was reused from a statue with another meaning and an unsuitable attribute, which was removed. However, Van Hamme's œuvre and career remain too little known to determine the answer. What we do know is that he too was trained at the Brussels Academy, from 1900 to 1904 , that he applied in vain for the Prix de Rome and that he completed a bust of King Leopold II and the inventive muscular figure of the god Boréas in Brussels's Parc Josaphat (plaster 1904, bronze 1922, installed 1923). ${ }^{43}$

On the Place du Vieux Marché aux Grains, in the western half of the city centre (fig. 1, no. 8), was placed Hommage à l'Italie by Georges Vandevoorde (1878-1964). Although several sources refer to its existence, no image of it has yet been found. It seems to have been rather modest from its description as 'un motif décoratif' (a decorative motif) and as a

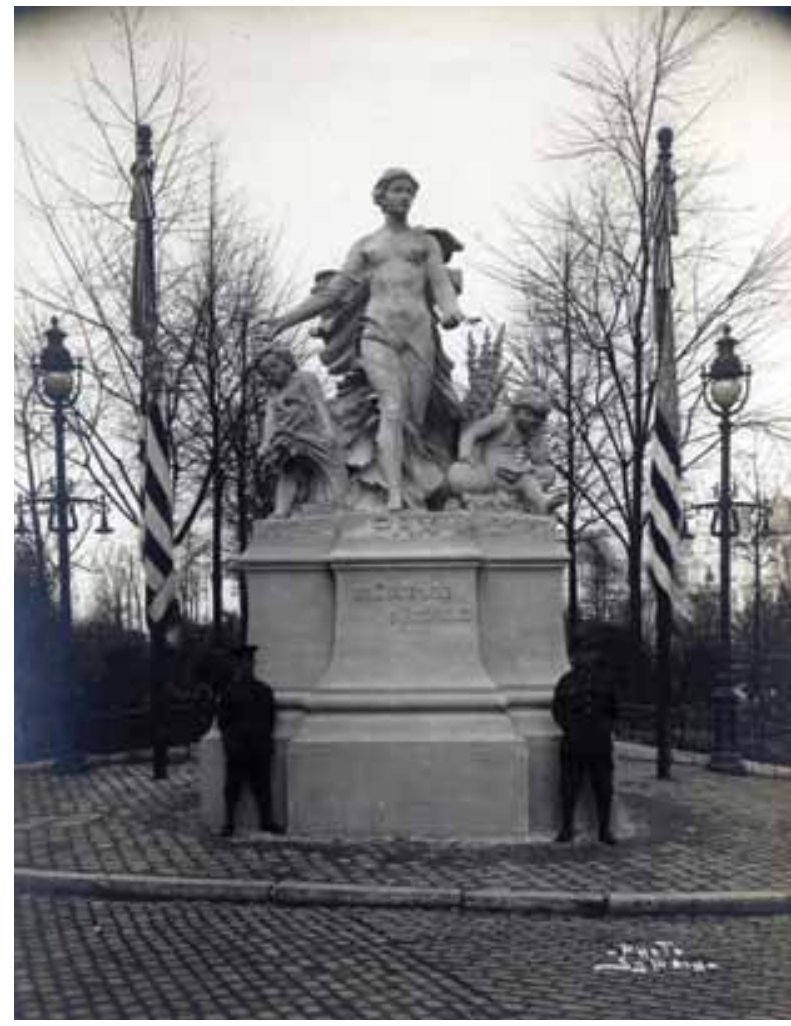
'Grand cartouche, écusson et drapeaux aux armes de l'Italie' (large cartouche, coat of arms and flags with armorial bearings of Italy)..$^{44}$ Presumably, this decorative sculptural object, possibly a bas- or haut-relief, incorporated no figures. Vandevoorde was trained in his native town of Courtrai, but moved to Brussels, where he became an apprentice of the sculptors Julien Dillens (like Lagae) and Victor Rousseau (like Grandmoulin). He made some works in ivory as well, and some followed the then innovative taille directe technique in stone and wood. In 1914 he won the competition for a bronze monument to a priest in Courtrai that, due to the war, was only completed in 1931. He realized several more public statues, funerary sculptures and war memorials, among others in Molenbeek-Saint-Jean and at the national shooting range (where Cavell was shot) in Schaarbeek, both in Brussels. ${ }^{45}$

On the place Surlet de Chokier (fig. 1, no. 9) was positioned perhaps the most original composition, entitled alternately Elle arrêta le flot, La Belgique 
9. Joseph François Van Hamme, À nos blessés, 1918

(photo: Brussels City Archive (Guerre 1914-1918 [Monuments provisoires...], C-1878) arrêtant le flot germanique or La vague, by the French-born Marquis Jean Eugène Alphonse de Pouilly (1877-1948) (fig. 10). A sculptural group integrated into a baroque portal with a fronton (featuring branches with oak leaves and a medallion with a Belgian clawing lion, with a crown on top) represents Lady Belgium in a long dress with her arms, feet and one breast bare, her left knee leaning on a rock, holding a flag in her left hand, as she fiercely pushes back a - figurative as well as literal - wave of German soldiers holding rifles. Their helmed faces are almost caricatures, rude and brutal, and it is likely that they would have induced a strong response from the public. With her right hand, the classically helmed la Belgique pushes back the chin of an advancing German.

The choice of iconography and the fact that de Pouilly authored a temporary monument for Brussels in 1918 probably has much to do with the fact that he was incarcerated in the same German camp (in the castle of Celle in Lower Saxony) as the adored Brussels Mayor Aldophe Max (1869-1939), as La Gazette writes. The nobleman de Pouilly, born in Verdun and married to a Belgian noblewoman, Jeanne-Marie Lejeune de Schiervel (1878-?) in Saint-Trond in 1900, exhibited only occasionally. At the Paris salons of the Société des Artistes Français, he displayed two plaster equestrian statues in 1912 and $1913 .{ }^{46}$ In 1919 he returned to the family castle in Cornay (French Ardennes) that had been used by the German army during the war. ${ }^{47}$

Sander Pierron, although seemingly uncertain about the exact number of temporary statues, mentions still another one in the adjacent municipality of Saint-Josse-ten-Noode, in front of the city hall (fig. 1, no. 10): La Belgique reconquise by Guillaume Charlier (1854-1925) (fig. 11). ${ }^{8}$ Once more, it concerns a woman with a flagpole, now leaning on it with a more resigned expression. The outstretched body of a dead soldier lies at her feet, in turn lying over a seemingly defeated (Belgian) lion. It seems to say that Belgium's ultimate victory was won at a high price. ${ }^{49}$

Presumably, most reviews omitted this monument because of its more marginal location away from the central city parcours and because it was not commissioned by the city of Brussels. Pierron, however, had published a monograph on Charlier in 1913, so it comes as no surprise that he included this public work. It is likely that the monument was Charlier's private initiative. As early as December 1915, the sculptor had officially proposed to the municipality of Saint-Josse to make (and pay for) a bronze statue for its fallen soldiers. In 1917 the municipal council was invited by the sculptor to see the final project. In September of that year he let the council know that he would make available 40,000 francs for the execution of the monument (excluding the plinth 


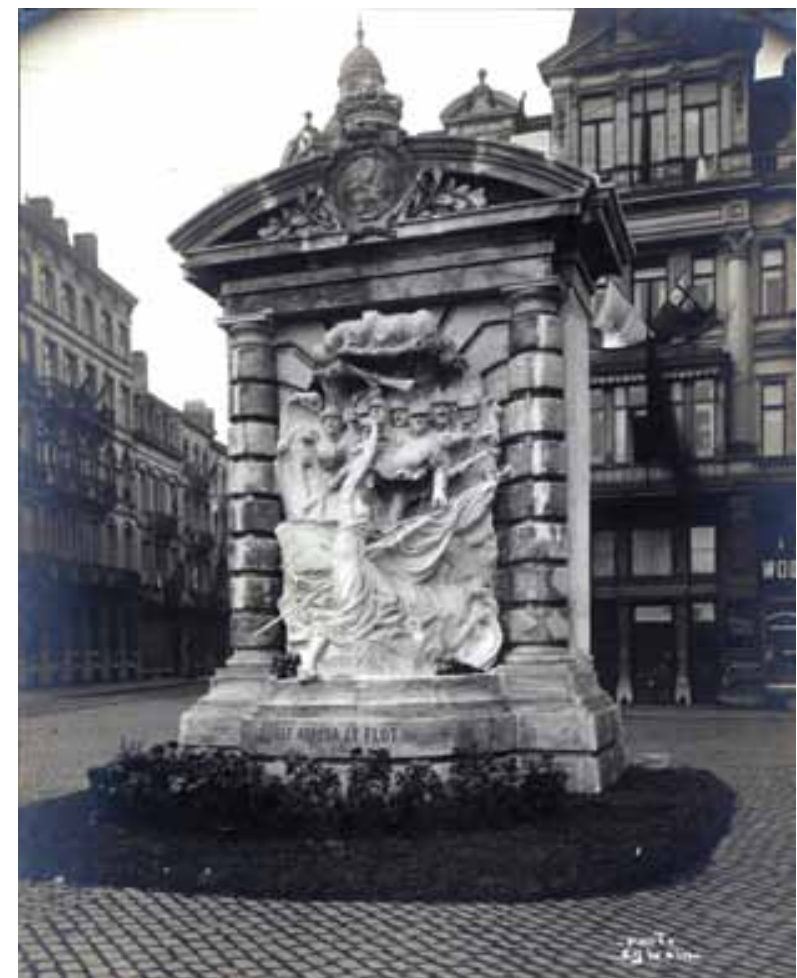

10. Marquis Jean Eugène Alphonse de Pouilly, Elle arrêta le flot (La Belgique arrêtant le flot germanique or La vague), 1918 (photo: Library Ghent University)

\section{The king's return}

and the placement which the municipality would have to finance). In November 1918, in the context of the Armistice, a version in stucco was placed in front of the city hall. It is not unlikely that this was actually the same object shown to the council members in $1917 .^{50}$

The earliest statue that was part of the ephemeral series was that for the French General Augustin-Daniel Belliard (considered one of Belgium's founding fathers) by Guillaume Geefs. This monument had actually already been inaugurated in 1836 as the first statue erected in the capital of the new nation (fig. 1, no. 11). Because of the festivities, it was temporarily embellished by Jean Delescluze, who was already very much involved in the 1918 decoration effort (fig. 12). This makes eleven sculptural attractions in total: ten monuments in stucco and one decoration of an earlier statue.

The festive re-entry of the king into the capital on 22 November 1918 was extensively covered by the press. Many journalists mentioned the monuments as a successful part of the decorations. The first wave of reviews appeared in the Belgian press immediately after the monuments were erected. These accounts generally herald the nobility of the initiative and describe the monuments as part of the city's festive decorations on the royals' arrival. They provide information about the causes represented by the monuments, their sculptors and location, sometimes in dithyrambic terms. On 19 November the liberal newspaper La Gazette wrote:

On the Grand' Place, the 'Brabançonne' radiantly arises, happy to finally express feelings suppressed for such a long time. 'The Belgian rises from the grave': Ah! Yes! He rises with his head high and a serene face, like that of the woman to whom Samuel has devoted all his patriotic ardour..$^{51}$

Most of these early reviews applaud the patriotism of the participating sculptors. Generally, they are mentioned by name, and their patriotic zeal is tied to their personal experiences during the war. La Gazette, for example, writes about the imprisonment of de Pouilly and the Brussels mayor, and $\mathrm{La}$ Presse de Bruxelles informs its readership that Wolfers was waiting for his son to return from the front while designing his sculpture..$^{52}$ Such references indicate that the statues succeeded in expressing experiences and feelings shared by the artists and the people of Brussels and Belgium alike. Some 


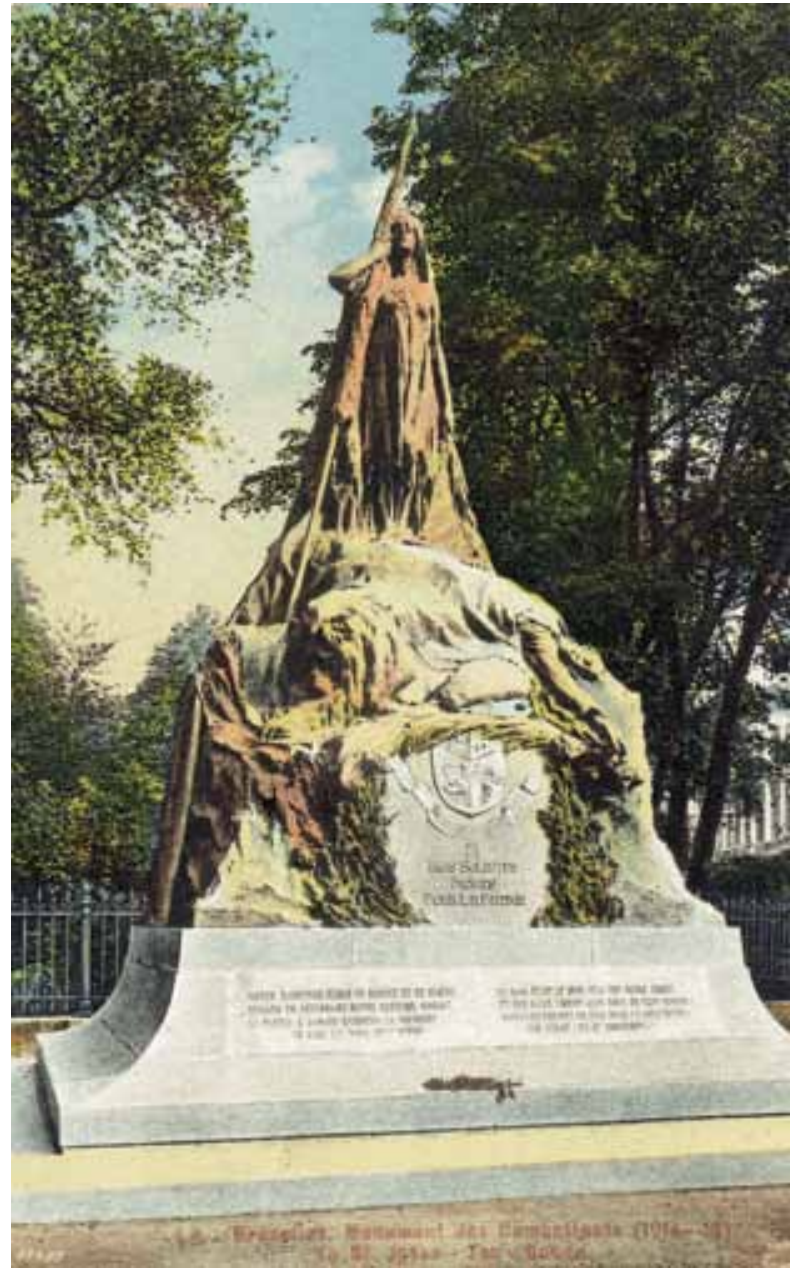

artworks are cited significantly more than others, notably those by Samuel (La Brabançonne), Marin (À Miss Cavell), Wolfers (Yser) and de Pouilly (La vague), but none of the works is disapproved of. The enthusiasm of the journalists was clearly stimulated more by the cause represented than the sculpture itself. The monument for Edith Cavell was particularly popular with British and Canadian visitors to the city.53

The liberal newspaper Le Belge Indépendant (published in London since 1914) was initially very positive. The reporter noted with satisfaction that the sculptors had not been inactive under the boche occupation and that they had contributed a great deal to the attractive appeal of the city during these festive days. He mentioned four statues: Lagae's King Albert and Belgian lion, $\mathrm{La}$ Belgique arrêtant le flot by de Pouilly, Wolfers's group (mistakenly ascribed here to Égide Rombaux, who in 1923 realized the monument for the war heroine Gabrielle Petit in Brussels) and Guillaume Charlier's Belgique (described as 'a worthy incarnation of the power of resistance').$^{54}$

A fortnight later, after most of the temporary monuments had been removed from public view, the same reporter sounded much more critical: 'Some had a certain allure, a generous
11. Guillaume Charlier, $L a$ Belgique reconquise, 1920, picture postcard (Marco Marcovici Bruxelles), $13.5 \times 8.7 \mathrm{~cm}$ (photo: collection of the authors) idea, beautiful lines, [...] The others didn't match the symbol they wanted to incarnate. They missed feeling and soul. They were nothing more than informal sketches. ${ }^{55}$ Although he was not explicitly writing about this particular series of monuments for the king's return, the journalist Léon Souguenet, writing under the nom de plume of Bob, added a critical note. He warned against a deluge of average-quality memorials:

Let's be wary of cheap memorials of poor quality, a threat that is surrounding us on all sides [...] Can you see that? [...] on all the squares, a Lady Belgium in bronze by a local artist [...] To make things worse, no doubt every Lady Belgium will be accompanied by a lion, that formidable Belgian lion. ${ }^{6}$

After interest in the royal entry had faded, this second wave of reviews delivered a more critical assessment of the sculptures' artistic merit, sometimes tied to the question of making them permanent. In the socialist newspaper Le Peuple, Sander Pierron, who would later write La sculpture en Belgique 1830-1930,57 devoted a lengthy article to the monuments from a specifically artistic point of view..$^{58}$ His central question was whether the temporary sculptures, conceived as heralding a new era, also represented a renewal in 


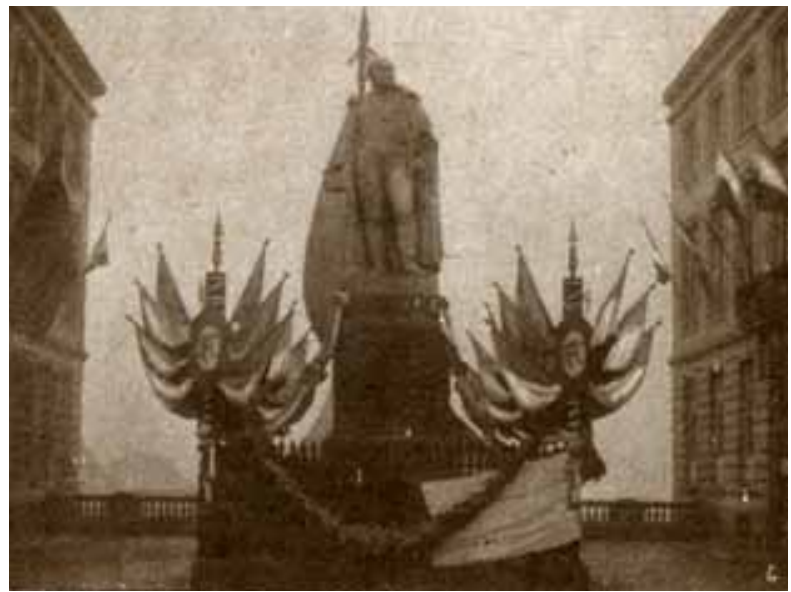

the arts, and he denied that this was the case. In his view, the 'excessive individualism of the effort', the lack of unity between the sculptures and their overall traditionalist approach prevented them from expressing a unique national identity. According to Pierron, the ensemble could not conceal the absence of a national Belgian sculpture school. Overall, the temporary sculptures were too classical, too formulaic and lacked novelty and audacity; the architectural plinths and settings were conventional and without invention. Even though Pierron called Wolfers's group 'logical, beautiful and expressive' and 'full of élan, force and grace',

12. Guillaume Geefs, AugustinDaniel Belliard, 1836, decorated by Jean Delescluze, 1918 (photo: Library Ghent University) he criticized the project's 'negation of a modernist orientation' and called for sculptors able to express post-war grief, aspirations and hopes. ${ }^{59}$ According to Pierron, all the sculptures (except for Charlier's, which he considers more intimate) had a monumental tendency and were explicitly conceived for the open air, and some artists did as such respond in the conception of their work to the democratic ideal of making the beaux-arts available to all, an idea already much in vogue in Brussels during the Belle Époque. ${ }^{60}$

\section{An open-air sculpture museum}

Before the war, Brussels was considered a liberal and progressive city with regard to the arts. In architecture too, the city knew its heyday during the Belle Époque, with art nouveau becoming visible in the streets. In galleries and at salons, one was able to see all things new in European art. ${ }^{61}$ The innovative art unions Les XX (1883-93) and La Libre Esthétique (1894-1914) especially invited French avant-garde art, including sculpture (e.g. Auguste Rodin, Camille Claudel, Henri Cros, Alexandre Charpentier, Albert Bartholomé). This was instrumental in influencing generations of younger sculptors whose work would be characterized by artistic individualism. ${ }^{62}$ None of the sculptors who took part in the 1918 project was a vingtist, however. Charlier was - he took Lambeaux's place in 1885 - but he did not receive an official commission in 1918. Charlier as well as Lagae and Samuel were invited for some exhibitions of La Libre Esthétique. ${ }^{63}$

The period also marked the high point of public sculpture commissions (architectural sculpture as well as monuments) throughout the country and especially in the capital, with important programmes of monumental sculpture, such as the Palais de Beaux-arts (c. 1879-86), the Place du Petit Sablon (c. 1880-90), the Botanical Garden (c. 1892-98) and the Parc du Cinquantenaire (c. 1888-1910). All involved several sculptors, including influential figures such as Van der Stappen and Meunier, who were both vingtistes and frequent exhibitors at La Libre Esthétique. ${ }^{64}$

In these same Brussels artistic circles, the concept of an open-air sculpture

336 | Sculpture Journal 26.3 [2017] 
museum was much discussed in the decades preceding the war, but despite several initiatives, this ambition was never realized. ${ }^{65}$ In 1891 , for instance, an open-air exhibition with temporary wooden sculptures was held in the Bois de la Cambre. The former sculptor and journalist Achille Chainaye (1862-1915), a founding member of Les $X X$, was responsible for the pieces' placement. Under the pseudonym of Champal, Chainaye pleaded in La Réforme for 'Popular sculpture. No more museums. Everything in the open-air' and for taking sculptures out of 'cold' museums and putting them in the open air on public roads alongside the promenades, where they could also be seen by labourers. ${ }^{66}$ The same 'socialist' suggestion was repeated in 1907 and around 1910.

In the pre-war years, L'Art Moderne, the avant-garde journal associated with Les XX and La Libre Esthétique, and its leftist editors Octave Maus and Edmond Picard, were fierce advocates of the plan to make Brussels an open-air museum of sculptures. When three statues by Auguste Rodin were exhibited temporarily (for a year and a half) in 1910-11, near the ponds of Elsene, the topic rose again. ${ }^{67}$ Maus deplored the fact that it was 'all only temporary' ${ }^{68}$ The defenders were aware of the statuemania problem, but pleaded not for more stone or bronze 'gentlemen' in suits in the streets, but for more 'noble figures' by Meunier and kindred colleagues, proclaiming that 'all modern sculptures should be placed in the urban landscape, to their own benefit'. ${ }^{99}$ The initiative in November 1918 should be seen in this context. The series of temporary monuments placed in the squares, parks and streets of Brussels as an open-air museum was certainly intended to appeal to the public at large.

\section{Temporary sculpture}

The placing of temporary sculptural decorations made of non-durable materials throughout the city had even earlier precedents. The uses of plaster for public sculpture are manifold. Plaster models of sculptures were an ideal way to present works at the yearly salons while trying to find a public or private commissioner to pay for their conversion into costly, durable materials..$^{70}$ In the case of commissions for public statues or monuments, plaster models, sometimes with a protective layer, were frequently placed in situ beforehand, in Belgium as elsewhere, to judge the proportions of the sculpture in relation to its immediate surroundings; to determine the ideal siting for decorum, historical or political motivations; for optimal visibility from afar; to investigate the reactions of the public, who had sometimes co-financed the artwork; or simply because the planned bronze version was not ready in time for the inauguration. Although these models were typically removed after a few weeks, days or even hours, they sometimes remained in situ for a much longer time than planned..$^{1}$

In the context of world fairs and expositions, which Belgium frequently organized during the Belle Époque (Antwerp, 1885 and 1894; Brussels, 1888, 1897 and 1910; Liège, 1905; and Ghent, 1913), temporary open-air statues on 
and around the exhibition pavilions, made in stucco (locally called 'staff technique'), were installed for the duration of the fair. Some were converted into more durable material after the exhibition..$^{22}$ Throughout the country, ephemeral sculptures were also erected on the occasion of religious, folkloric and historical pageants, such as the ambitious historic parades organized in several Flemish cities in the mid-nineteenth century. These featured pageant wagons full of decorations in stucco, designed by sometimes famous architects, sculptors and painters, peopled by many figures in historical costumes. Another example is the septennial Virga Jesse parade in Hasselt, during which local street committees built monumental religious scenes in wood and plaster and performed on pageant wagons in the fashion of medieval English cycle plays. ${ }^{73}$

However, it is the tradition of using ephemeral sculptures for annual patriotic celebrations in the Belgian capital that is most relevant here. Indeed, the festivities of 22 November 1918 strongly echoed the traditional patriotic festivities held on the national holiday (21 July) since 1831. On these days, except during the war when the festivities were forbidden by the occupying regime, the streets of Brussels underwent a true metamorphosis. With the help of architects, sculptors, painters and decorators, the city was reshaped into a grand open-air fair with flags and pennants, flower arrangements, paintings and temporary sculptures and architectural monuments..$^{74}$ From its start, the contribution of Belgian artists had been crucial, and their presence was considered a national tradition long predating the founding of the nation: 'in every epoch of our history, Belgian art has largely contributed to celebrating the fatherland, and the grandest artists have not looked down upon attaching their name to ephemeral creations whose glory helped to perpetuate the memory'?5

For centuries, Belgian artists had been involved in preparations for the festive entries of rulers and royal families, as well as the celebration of national jubilees. A strong tradition existed of ephemeral sculpture in public spaces as part of these festivities. ${ }^{76}$ The involvement of artists in national jubilees was only heightened with the emergence of the nation-state in 1830 . The artworks represented the grandeur of the nation while contributing to it. They had a legitimizing, educational and commemorative function. Artistic contributions were the result of close collaborations between architects, sculptors, painters and decorators, and commissions were usually handed to established artists. Some of the tutors of the artists under scrutiny here, such as Geefs and Van der Stappen, ${ }^{77}$ made ephemeral and permanent sculptures for these occasions. Of these short-lived (and sometimes later made permanent) creations, the triumphal arches, built as powerful signs of recognition and gratitude to the king, were the most prolific. The constructions and adjoining sculptures depicted the glorious past and future of the country and focused on the monarchy and the constitution to legitimate the nation-state. ${ }^{78}$ These traditional elements were present in the November 1918 monuments too, but they were complemented by war-related causes and imagery. 


\section{Temporary sculpture and the First World War}

In the context of the First World War, the use of temporary monuments gained new meaning. For the first time, a total war was being fought. The massive engagement of civilians revealed a pressing urge to commemorate specific and often local events or to publicly express and share grief. Yet the financial and logistic structures required to build permanent monuments were often missing or limited. This was already the case during the conflict. Across Europe, the result was ad hoc and often on-site monuments, such as flower shrines or simple wooden columns or crosses, mostly temporary and sometimes testifying to a remarkable ingenuity. ${ }^{79}$ For example, in early 1915 in Stuttgart, a snow sculpture of the German Field Marshal Paul von Hindenburg - at that time already known in Germany as 'the victor of Tannenberg' - was presented in an ice skating rink. ${ }^{80}$ It would take another thirteen years for an official Hindenburg/Tannenberg memorial to be built. ${ }^{81} \mathrm{~A}$ famous, more robust example is the Hyde Park memorial shrine in London: a 24-foot spire with Allied flags around the top placed on a Maltese cross-shaped base. It was inaugurated on 4 August 1918 (four years after Britain's entry into the war) and attracted vast audiences. Due to its popularity, the shrine remained in situ for over a year and prompted further debates on official war memorials. ${ }^{82}$ In October 1918 in Paris, a plaster model of François Sicard's (1862-1934) Au poilu was erected on the Champs-Élysées. Clearly visible on its pedestal was a sign reading 'subscribe to the loan' to attract funding. ${ }^{83}$

Such larger wartime temporary monuments were rare and often forbidden in occupied territories such as Belgium, where one had to resort to inconspicuous improvised shrines or memorials. ${ }^{84}$ In the context of the occupation, religious celebrations often took on patriotic undertones. Throughout the war, All Saints Day was celebrated with special fervour in occupied Belgium. The Catholic tradition of laying flowers on the tombs at the local cemetery turned into massive commemorations of the fallen, reluctantly tolerated by the occupier. Next to the public's abundant decorations of the graves with chrysanthemums, paper flowers and wreaths, local authorities and patriotic associations erected improvised funerary steles and temporary monuments. For All Saints' Day in 1915, for instance, a temporary monument by an unnamed sculptor (the press only mentioned that he was a pupil of Thomas Vinçotte) of a Belgian lion holding the Belgian flag in its claws mounted on a stone plinth was erected on the cemetery of Saint-Josseten-Noode. ${ }^{85}$ In November 1916 a pyramid-shaped memorial was erected on the cemetery of Ixelles, and a sculptural group embellished the soldiers' cemetery in the adjacent municipality of Etterbeek. ${ }^{86}$

In the first months after the war, the need for places of commemoration was deeply felt by the population, and questions immediately arose about who was to build and finance monuments and to whom they should be erected. ${ }^{87}$ Yet official bodies on the national and local levels - overwhelmed with financial problems - were often reluctant to make decisions. Moreover, in June 1918 the Belgian Parliament had already decided that the state would 
only subsidize war memorials with an explicit artistic character and only up to one-third of their cost. This decision further curbed local authorities, and thus the building of official monuments did not immediately take off after the Armistice. Temporary monuments were an answer to this need. They were less cumbersome to realize and allowed at least temporarily for an actual lieu de mémoire (to use Pierre Nora's concept) to emerge.

The monuments erected in Brussels in November 1918 were the first, but certainly not the last, post-war emanation of this need. They were quickly followed by other initiatives. In December, for example, a patriotic ceremony at the cemetery in Ixelles took place at the foot of a newly erected temporary monument by Isidore De Rudder (1855-1943), who had his studio in Ixelles. The monument, entitled Souvenir, was referred to in a newspaper article as a temporary model of a larger sculptural set (consisting of several separate sculptures, including a group representing the rather atypical topic of 'the funeral of a hero') to be made by De Rudder later on. ${ }^{88}$ As such, the group was never completed. However, in 1918 the commune of Ixelles bought from De Rudder his marble work La vieille fontaine (The Old Fountain), which he had finished before the war, and installed it at the Place Charles Graux. De Rudder also contributed one of the four life-size bronze soldiers erected in the war graves section of the local cemetery in $1923 .{ }^{89}$ That year also saw the inauguration in Paris's Place de l'Alma (now Place de la Reine Astrid) of the still-extant Monument de la reconnaissance belge à la France by De Rudder. It features two women holding hands in friendship, that is, Belgium and France (wearing a Phrygian cap), with two putti between them.

By the summer of 1919, in anticipation of the building plans for a great national war memorial, ${ }^{\circ \circ}$ a robust temporary cenotaph was placed in the Royal Park in Brussels for the national jubilee and the subsequent Marche de la Victoire (21-22 July 1919). The Brussels cenotaph was designed by the city architect François Malfait and put on exactly the same spot where barely six months earlier Wolfers's monument À nos héros had stood. Around the same time, similar cenotaphs were placed in Paris for the national holiday (14 July) and in London for the Peace Parade (19 July)..$^{91}$ Like the one in Paris placed under the Arc de Triomphe, ${ }^{92}$ the Brussels cenotaph was removed immediately after the ceremonies, whereas the British counterpart, by the architect Sir Edwin Lutyens, placed in the middle of Whitehall, remained in situ and was replaced with a permanent stone cenotaph in $1920 .{ }^{93}$

\section{A lasting legacy?}

The statues erected in Brussels in 1918 were made from wood and plaster without any immediate prospect of making them permanent, even if $L e$ Belge Indépendant called them 'plaster models of future commemorative monuments' ${ }^{4}$ According to the same journal, the statues were intended to remain in place until Christmas. Some stayed longer, but by February 1919 all the sculptures had been removed from the public space and most likely either 
demolished or returned to their authors. ${ }^{95}$ However, the monuments had struck a chord, and several plans to perpetuate them were initiated.

In early December 1918 an enthusiastic reader of Le Soir advocated in a published letter to the editor casting the temporary monuments in bronze and financing them by public subscription. In response, Le Soir recommended the selection of the most meritorious monument: 'however, one could select one of the best and erect it by public subscription'. ${ }^{6}$ Even if this early initiative seems to have died a quiet death, this is eventually what happened: three of the ten temporary monuments in stucco were given a permanent character, albeit in other locations, and with minor changes: Lagae's monument to King Albert, Charles Samuel's La Brabançonne and Guillaume Charlier's La Belgique reconquise. The latter two represent Lady Belgium holding the national flag with her right hand.

The location of a permanent version of La Brabançonne was already a point of discussion in January 1919, when the city architect Malfait suggested the Place de la Chapelle in the popular Marolles neighbourhood. ${ }^{97}$ This statue was not only the last stucco monument to be removed from its initial location (Grand-Place) in February 1919, but it was also the only monument that reappeared temporarily shortly afterwards. In April 1920 the plaster monument was installed in the Royal Park facing the Royal Palace (almost where Lagae's monument had been in 1918) on the occasion of the first post-war Brussels Commercial Fair. The monument was now positioned on a new plinth, with the same inscription but without the explicitly war-related bas-relief decoration. It seems to have been removed shortly afterwards. A rare picture postcard of the Commercial Fair is the only witness of this short, temporary reappearance (fig. 13).

In 1930 the Brabançonne monument was once more reused, this time for the celebration of the Belgian centenary. Samuel had by then collaborated on war memorials in Edingen (1920) and Ixelles (1926). ${ }^{8}$ Prior to the festivities in 1930, money was raised by public subscription, and the statue was now cast in bronze by Brussels's Compagnie des Bronzes, where the statue would remain in store for some time, as its siting was subject to long discussions. Finally, it was decided in August 1930 to relocate it to the smaller, slightly peripheral Surlet De Chokier square, which was in November 1918 the location of de Pouilly's La vague. ${ }^{99}$ At that time, the statue was put once again on a new pedestal and reframed by a new inscription: the first couplet of the national anthem, La Brabançonne. ${ }^{100}$

Charlier, in his turn, proposed to the municipality of Saint-Josse that he would make and pay for a bronze statue to its fallen soldiers in December 1915. He repeated this offer both in September 1917, when a model of the work was finished, and once more in January 1919, presumably around the time of the removal of the plaster model ${ }^{101}$ From the beginning, the city council was very pleased with the generous offer and anticipated placing the work near the war graves in the local cemetery. Between January 1919 and March 1920 the council continued to deliberate on the ideal location. Some advocated the cemetery as the best place, close to the war dead. Others argued that it should 
replace the current Monument aux Eaux du Bocq, dedicated to the former burgomaster Armand Steurs and the River Bocq, on the intersection between the Avenue Bischoffsheim and the Rue de l'Astronomie. Finally, by ten votes to eight, the latter option was chosen. Ironically, the Bocq monument by Joseph Kemmerich (1868-?) and the architect Léon Sneyers was the result of a competition in 1903 and was chosen by a jury including Guillaume Charlier himself, with Meunier and Dillens. Yet it was considered too modern by many: its iconography was confusing and its large architectural plinth 'cubist'. Moreover, Kemmerich had been recently sentenced for collaboration with the Germans during the war. The Bocq monument was thus melted down and the bronze recuperated to cast Charlier's work, so that little additional funding was needed..$^{102}$ On 21 July 1920 it was inaugurated as the first permanent war memorial to the First World War in Brussels, only a stone's throw from its earliest location in $1918 .^{103}$

The monuments dedicated to individuals, for example nurse Edith Cavell (by Marin) and King Albert (by Lagae), were not made permanent as such. However, both figures were honoured by several sculptors in the years to follow. Several busts of King Albert were erected throughout the country, but none of these followed the Roman-style representation of the temporary monument by Lagae. After the king's unexpected death in 1934 and upon the commemoration of his death, several cities erected equestrian statues of him, ${ }^{104}$ though never with laurel leaves, but instead mostly with an Adrian helmet, referring to the king-soldier. In 1930, when Lagae made a war memorial for the Walloon village of Monceau-sur-Sambre, he reused the plinth of his 1918 memorial, now with the more common inscription 'À ceux qui moururent pour la Patrie 1914-1918', including the lion devouring the eagle, now in bronze. A bust of Minerva substituted for the bust of King Albert.

In November 1918 rumour had it that the Cavell monument by Marin would be eternalized in stone and placed at the shooting range where Cavell had been killed or in the front yard of the nursing school where she had worked as matron. ${ }^{105}$ Although these rumours did not prove true, the Cavell monument was among those cited most often as a contender for being made permanent. Even the French Le Petit Journal of 22 November 1918 mentioned governmental plans to erect a monument to Edith Cavell, on whose tomb flowers were laid that day, just as on the tombs of the other 40 fusillés. ${ }^{106}$ Le Belge Indépendant wrote, 'Of all these monuments, only one, so it seems, is destined to survive, the one for Miss Edith Cavell, by Morin [sic].'107 There was no objection whatsoever to the idea that the valiant British nurse deserved a monument. The design by Marin received a lot of praise, but also some criticism concerning its sketchy execution, lack of coherence and the rather voluminous tumulus. The advice of one journalist was clear: 'À reviser!' (Redo!) ${ }^{108}$

The temporary Cavell monument in Brussels post-dated the memorial in her home town of Norwich (by Henry Pegram, 1862-1937), which was unveiled by the British Queen Alexandra on 12 October 1918. However, it predated by two years the large memorial by George Frampton (1860-1928) in St Martin's Place in London. By that time, in March 1920, another less monumental 
but permanent statue had been installed in Brussels on another site. The monument by Paul Dubois (1859-1938), a loyal vingtist and exhibitor at La Libre Esthétique, was dedicated not only to Cavell but also to her Belgian fellow nurse Marie Depage, who had died on RMS Lusitania in May 1915. In 1919 both women had already been commemorated together on a medal by Armand Bonnetain (1883-1973), commissioned by the nursing school. The new monument was modest in scale and represented two allegorical figures, Time and Glory, presenting flowers and laurel leaves to Cavell and Depage, who are present not through portraits, but by the inscription of their names on the tomb-like pedestal. ${ }^{109}$

Accordingly, it seems that only Charlier's La Belgique reconquise, Samuel's La Brabançonne and Lagae's monument to King Albert were reused for later monuments. This is surprising, since several of the sculptors commissioned, notably Georges Vandevoorde, Léandre Grandmoulin and Jacques Marin, as well as the architect François Malfait, moved on to make war memorials in Brussels and elsewhere in the 1920s and 1930s. However, one could argue that the temporary monuments did set the tone in style and themes for the permanent war memorials erected in Belgium throughout the interwar years. Commonplace dedications such as à nos soldats morts pour la Patrie or à nos héros featured on the early temporary monuments, and figures such as King Albert, La Brabançonne or the Belgian poilu were commonly used in the war memorials. Several symbols that featured on the temporary monuments were reused in permanent memorials as well, for example the Belgian lion devouring the German eagle, Belgian flags, laurel wreaths and so on. Yet most of these elements can hardly be called original. They had been used throughout the war and stemmed from iconographic imagery that predated the First World War. In that respect, the real impact of the 1918 temporary monuments on post-war sculpture was limited.

13. Foire Commerciale de Bruxelles. Monument de la Brabançonne et Grand Bassin, 1920, picture postcard (Albert) (photo: collection of the authors)

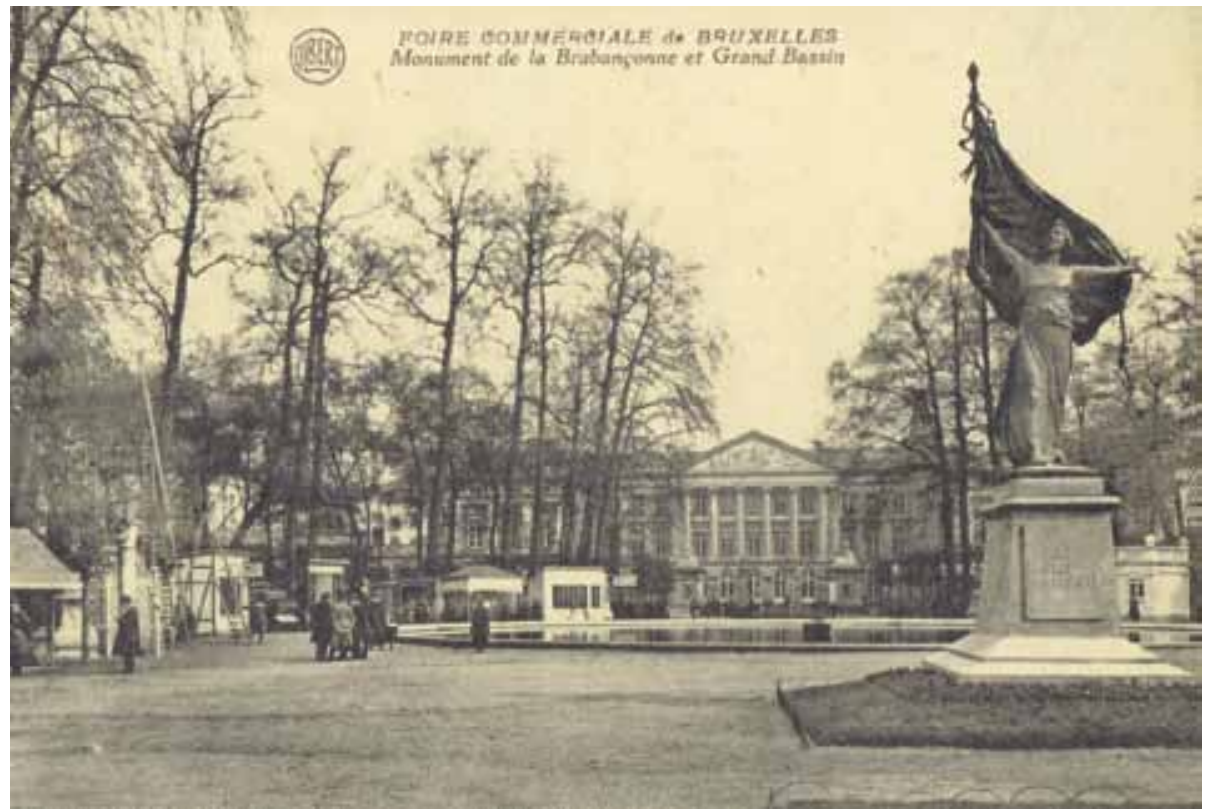


Compared to the international avant-garde en vogue at the time, the temporary and the permanent monuments were designed in a fairly academic or realist-allegorical style, indebted to the nineteenth-century historicist sculptural tradition. In Belgium, as elsewhere, very few avant-garde sculptors made war memorials. ${ }^{110}$ After all, memorials were not autonomous museum pieces but commissioned works ordered mainly by local communities, with particular demands concerning form and content and with a specific function. They had to appeal to surviving relatives, local inhabitants and society at large. Their public siting and the fact that they were often co-financed by the public (by public subscription or through communal taxes) called for a straightforward, uplifting, recognizable and inoffensive figurative design. ${ }^{111}$

Moreover, in 1918, for a younger generation of sculptors born in the 1880s, the time was not right to embark upon war memorials. Rik Wouters had died during the war. Georges Vantongerloo (1886-1965), who would become a pioneer of abstract sculpture after 1917, stayed in the Netherlands as a refugee after being wounded at the front, and moved to France shortly after the war. Oscar Jespers (1887-1970), who chose Cubism from 1918 onwards, was then only at the beginning of his sculpting career. In 1924 he would make a war memorial in Oostduinkerke, but this is still quite realistic compared to his Cubist artworks from that period. As from the 1920s onwards, another, more stylized sculpting style would manifest itself, in Belgium as abroad.

In November 1968 the sculptor Robert Delnest (1904-80), himself a student of Paul Dubois (author of the 1920 Cavell-Depage monument), was asked by the Brussels municipality of Molenbeek-Saint-Jean to design a sculpture to mark the fiftieth anniversary of the events of 22 November 1918. Although intended as a permanent sculpture, his remarkably abstract work, titled $\mathrm{La}$ Joyeuse Entrée en 1918 de S.M. le Roi Chevalier Albert, was removed from the public space in 2009. ${ }^{112}$

\section{Conclusion}

The series of ten temporary monuments in Brussels in November 1918 was an exceptional ensemble of commemorative structures, in view of the fact that the first permanent war memorials were only erected in Brussels from 1920 onwards. Not only are the scale of the series and the sculptural endeavour of several of the monuments remarkable, but also the time span of the materialization. Erected barely a fortnight after the Armistice, different elements contributed to this quick initiative and its rapid realization. First, the sculptors involved were inventive in reusing designs made before or during the war. Motivated by patriotic fervour, sometimes personal grief, but certainly the prestige of an official commission and the possibility of showing their work in a public space, many seized the opportunity and hastily executed their work in stucco. Secondly, on the official side, it is clear that the usual procedures for public sculpture were not followed. Next to a number 
of spontaneous contributions, sources reveal how specific causes had to be covered for diplomatic reasons, and sculptors were called upon to meet this need. Since the initiative was taken by the Brussels City Council - without the involvement of third parties or the national government - decisions could be made at the council's or even the city architect's discretion. This allowed fast decision making. Thirdly, the template of almost a century of open-air patriotic celebrations, pre-discussed ideas about the potential of Brussels as an open-air sculpture museum and a certain familiarity with temporary memorials made the initiative a not unusual concept and practice.

The 1918 monuments series presented individual artworks in public spaces and in so doing reconfirmed the grandeur of the nation and its renewed international appeal. It marked the apotheosis of national unity which was soon to be lost, perhaps foreshadowed in the lack of formal unity between the different monuments. Despite the sculptors' great efforts to finish their temporary statues in time, only two of them were later realized permanently in Brussels. Yet between 1920 and $1935,{ }^{113}$ Brussels and its municipalities would see the erection of more than thirty war memorials, some even designed by the same sculptors and mostly in an academic style, conforming to the international trend. While some of the 1918 monuments, such as those by Wolfers, Charlier or de Pouilly, could be considered quite original at their time of creation, none, as Sander Pierron rightly pointed out, truly created a new artistic élan that matched the glorious rebirth of the nation in November 1918. Considering their roots in the long-standing tradition of civic pageantry, they rather magnify an era slowly coming to an end than herald a new one.

\footnotetext{
1. See, for example, D. G. Troyansky, 'Monumental politics: national history and local memory in French "monuments aux morts" in the Department of the Aisne since 1870', French Historical Studies, 15, 1, 1987, pp. 121-42; A. Becker, 'Monuments aux morts après la guerre de sécession et la guerre de 1870-1871: Un legs de la guerre nationale?', Guerres mondiales et conflits contemporains, 167, 1992, pp. 23-40; J. E. Young, 'Ecrire le monument: site, memoire, critique', Annales: Economies, Sociétés, Civilisations, 48, 3, 1993, pp. 729-43; A. Borg, War Memorials from Antiquity to the Present, London, Leo Cooper, 1991.

2. For an overview, see the online database of war memorials in the north of France and Belgium constructed by a research team of the Université de Lille 3: http:// monumentsmorts.univ-lille3.fr/ (accessed 8 November 2017). The database is a work in progress but aims to be exhaustive by the end of the project.

3. S. Claisse, 'Pouvoir(s) et mémoire(s). L'État belge et les
}

\author{
monuments aux morts de la Grande \\ Guerre', in S. Jaumain, M. Amara, B. \\ Majerus et al. (eds), Une guerre totale? \\ La Belgique dans la Première Guerre \\ Mondiale. Nouvelles tendances de \\ la recherche historique, Brussels, \\ Algemeen Rijksarchief, 2005, \\ pp. 545-59; A. Prost, 'Les monuments \\ aux morts: Culte républicain? Culte \\ civique? Culte patriotique?', in $\mathrm{P}$. \\ Nora (ed.), Les lieux de mémoire, \\ Paris, Gallimard, 1984, pp. 195-225. \\ The heavily debated official national \\ monument in Brussels finally took \\ the shape of a memorial for 'the \\ unknown soldier' and was erected \\ only in 1922. Most local monuments \\ (cities and parishes) were \\ inaugurated in the 1920s (see http:// \\ monumentsmorts.univ-lille3.fr/) \\ 4. Hitherto unknown primary \\ sources found by the authors \\ have shown that no less than ten \\ temporary monuments were \\ erected on the occasion of the \\ re-entry of the king. In previous \\ publications, only eight temporary \\ monuments were acknowledged. \\ See S. Claisse, Du soldat inconnu \\ au monuments commémoratifs \\ Belges de la Guerre 14-18, Brussels,
}

Académie Royale de Belgique, 2013; C. Kesteloot, 'Une nouvelle joyeuse entrée dans Bruxelles libérée', in C. Kesteloot (ed.), Albert \& Elisabeth. Le film de la vie d'un couple royal, Brussels, Mardaga, 2014, pp. 86-97; L. Van Ypersele, E. Debruyne and C. Kesteloot, Brussel. De oorlog herdacht (1914-2014), Waterloo, Renaissance du Livre, 2014.

5. This event is sometimes referred to as the Festive Re-Entry of the Royals. The initial Joyous Entry of Albert I and Elisabeth had taken place in 1910, a few months after the king's coronation (December 1909).

6. Kesteloot, as at note 4 .

7. G.V., 'La cité de beauté', Le Belge Indépendant, 13 December 1918.

8. Le Belge Indépendant, 13 December 1918.

9. The route of the procession is described in several newspaper articles. See, for example, 'Le retour triomphal de nos héros', Le Soir, 23 November 1918.

10. Conseil communal de la ville de Bruxelles, Bulletin Communal de la Ville de Bruxelles (tôme 2), 1919, pp. $972-73$.

11. 'A Bruxelles', Le Matin, 20
November 1918: 'On a commandé également aux sculpteurs des groups monumentaux en stuc.'

12. Le Matin, 20 November 1918

13. 'La décoration de la ville', $L a$ Gazette, 19 November 1918.

14. S. Claisse, 'Les monuments aux morts', in L. Van Ypersele and E. Debruyne (eds), De la guerre de l'ombre aux ombres de la guerre, Brussels, éd. Labor, 2004, p. 65.

15. P. Derom, G. Marquenie and V. Everarts, Monuments and Statues of Brussels. Catalogue Raisonné, Brussels, Patrick Derom Gallery Pandora, 2002, cats. 7-74, 7-149, 12-10, 15-5, 7-88.

16. 'Pour le retour de nos souverains. Les décorations de Bruxelles: un demi-million de crédit voté', Le Soir, 18 November 1918.

17. La Gazette, 19 November 1918. The statues by Wolfers, Lagae, Grandmoulin, de Pouilly, Marin and the decorations of Delescluze were already in place on 19 November.

18. Le Soir, 23 November 1918.

19. S. Pierron, 'Les arts plastiques. Les sculpteurs de la victoire', $L e$ Peuple, 4 December 1918: 'Floraison pas tout à fait spontanée, car si 
d'aucunes de ces oeuvres furent réalisées aussi rapidement que s'affirma la victoire de nos armées, d'autres avaient été longuement conçues et exécutées dans le silence des ateliers.'

20. W. Adriaenssens, research paper, 'Salons en tentoonstellingen in Brussel tijdens de Eerste Wereldoorlog' ('Salons and exhibitions in Belgium during the First World War') presented at the conference 'Before and After? Continuity or Rupture? Belgian Art around World War I' at the Royal Museum of Fine Arts in Brussels, 24 November 2016 .

21. La Gazette, 19 November 1918

22. After the war, tensions rose between different groups who had had different war experiences (at the front, in occupied Belgium, in German labour camps, as refugees) as to who had suffered most and which experiences should be commemorated. These tensions also influenced post-war decisions about monuments. Claisse, as at note 4 , p. 54; Van Ypersele, Debruyne and Kesteloot, as at note 4, p. 94 .

23. 'à la Grand'-Place, la Brabançonne, de Samuel, entraîne, d'un beau mouvement la foule séduit [sic] par son chant. M. Jacques Marin s'est souvenu du martyre de miss Cavell et le symbolise par l'effigie d'une femme enchaînée, que suivent d'autres femmes en larmes. Au Mont des Arts, M. Grandmoulin salue l'Amérique, qui nous porta la paix avec la victoire. Place Saint-Jean, M. Mascré nous invite à songer aux morts, et représente un soldat couché, soutenu par une infirmière, par la Patrie elle-même. Au Parc, M. Wolfers unit dans une belle composition les deux races unies de Flandre et de Wallonie. Et de ces monuments improvisés pour la fête des rues, un des plus saisissants est celui d'un artiste français, le marquis de Pouilly, qui dresse sur la place Surlet de Chokier, sous une porte d'architecture militaire, la Belgique frémissante, repoussant d'un poing énergique l'ennemi envahisseur. Ainsi, les artistes, le peuple, chantent un poème d'enthousiasme, un hymne de victoire.' Le Soir, 23 November 1918.

24. Le Matin, 20 November 1918; C. Engelen and M. Marx, Compagnie des Bronzes de Bruxelles. Archief in beeld, Brussels, Algemeen Rijksarchief, 2002, pp. 348-49.

25. Adriaenssens, as at note 20.

26. Le Peuple, 4 December 1918.

27. J. Ogonovsky in J. Van Lennep, De 19de-eeuwse Belgische beeldhouwkunst: Catalogus, Brussels, Generale Bank, 1990, pp. 550-53; L. T. Moustiquaires, 'Charles Samuel', Pourquoi Pas?, 4, 197, 1914, pp. 1487-88.

28. In the biography by John Goddeeris, a picture of the bust on a different, somewhat obelisk-shaped plinth with flower ornaments is included. There is a lion at the foot of the monument (similar, but not identical, to the one used in Brussels). There is no eagle. The picture was most likely taken in his studio, which suggests that the plinth was a try-out by the artist. J. Goddeeris, Jules Lagae. Een biografie, Ieper, West-Vlaamse Gidsenkring, 1998, p. 109.

29. https://www.wardeadregister. be/nl/content/lagae-o (accessed 8 November 2017)

30. The bust was commissioned by the National Bank of Belgium in 1907 After Albert's coronation (December 1909) the bust was placed in the office of the governor, next to Samuel's bust of Queen Elisabeth. Of this bust, at least four marble and two plaster copies exist. Van Lennep, as at note 27 , p. 474 ; Goddeeris, as at note 28 , pp. 86-87, 65-67.

31. A photograph of the plaster model on a high pedestal in the Fonds Fonderie Nationale in the Brussels archives is reproduced in C. Engelen and M. Marx, Beeldhouwkunst in België vanaf 1830 , Brussels, Algemeen Rijksarchief en Rijksarchief in de Provinciën, 2002, p. 1030.

32. Van Lennep, as at note 27 , pp. 471-76; Engelen and Marx, as at note 31, pp. 1026-31; Goddeeris, as at note 28 , pp. 109-28.

33. W. Adriaenssens, 'Philippe Wolfers (1858-1929). Kunstenaar en zakenman. De ontwikkeling van een artistiek oeuvre ten dienste van een onderneming', $\mathrm{PhD}$ thesis, Brussels, Vrije Universiteit Brussel, 2007, p. 352, no. 243 (Les cerceaux or Les couronnes); p. 387 , no. 268 ( $\dot{A}$ nos héros); p. 477, no. 332 (Yser). The authors wish to thank W. Adriaenssens for additional information supplied via email.

34. L'évènement illustré, 27 November 1918, p. 187: 'Au Palais de la Nation, M. Philippe Wolfers a élevé le monument grandiose dont il a fait cadeau à la ville.' See also Conseil communal de la ville de Bruxelles, as at note 10 .

35. His son Marcel (1886-1976) would see his Monument to the Heroes of the First and Second World Wars erected in the Brussels municipality of Ganshoren, and completed several more monuments. Derom, Marquenie and Everarts, as at note 15, p. 91, cat. 11-4; C. Vandervelde, Les champs de repos de la Région Bruxelloise, Brussels, C. Vandervelde, 1997, p. 300.

36. 'À Bruxelles', L'Echo Belge. Journal quotidien du matin paraissant à Amsterdam, 3 November 1915. On the monuments to Edith Cavell, see S. Malvern, "'For King and Country”: Frampton's Edith Cavell 1915-1920 and the writing of gender in memorials to the Great War', in D. Getsy (ed.), Sculpture and the Pursuit of the Modern Ideal in Britain, c.188o1930, Aldershot, Ashgate, 2004, pp. 219-44; L. Engelen and M. Sterckx, 'Remembering Edith and Gabrielle. Picture postcards of monuments as portable lieux de mémoire', in B. Vandermeulen and D. Veys (eds), Imaging History. Photography after the Fact, Brussels, ASP Editions, 2011, pp. 87-103.

37. S. Orloff in Van Lennep, as at note 27, pp. 489-9o.

38. B. Fornari, in Van Lennep, as at note 27, p. 491; O. Maus, 'Louis Mascré', L'Art Moderne, 18 February 1900, p. 54.

39. Le Peuple, 8 December 1918.

40. J. Van Lennep in Van

Lennep, as at note 27, p. 430 .

41. This monument is mentioned in A. Van Ruyselvelt, Stadsbeelden Antwerpen anno 2001. Een gids-inventaris van de beelden en monumenten, Antwerp, Stad Antwerpen, 2001, pp. 107-08. 42. La Fédération Artistique, 7 June 1899, no. 34; L'Art Moderne, 27 October 1901, p. 361; as cited by Van Lennep, as at note 27, pp. 429-31.

43. Engelen and Marx, as at note 31, pp. 1642-43; Derom, Marquenie and Everarts, as at note 15, pp. 19-40.

44. 'La décoration de nos rues et de nos places publiques', Journal de Bruxelles. Politique, Littérature, Commerce, 23 November 1918

45. Engelen and Marx, as at note 31, pp. 1616-19; Derom, Marquenie and Everarts, as at note 15 .

46. Le Noël. Revue hebdomadaire illustrée pour la jeunesse, 19, 945, 1913. p. 1 (cover image); P. Sanchez (ed.), Les catalogues des Salons, Paris, L'échelle de Jacob, 2014, nos. 1912-3968 1913-3969. A similar clawed, crowned lion as on the monument also features centrally in the armour of the French family de Pouilly.

47. 'Un monument à nos héros', $L a$ Presse de Bruxelles, 17 November 1918; La Gazette, 19 November 1918.

48. 'nous avouons de ne pas trouver dans ces huit ou dix monuments [...]'. He describes nine monuments in more detail. Le Peuple, 4 December 1918. The monument by Charlier is also mentioned in Le Belge Indépendant of 13 December 1918.

49. Charlier was an apprentice in the Brussels studios of first the romantic sculptors Guillaume Geefs (1805-83) and Eugène Simonis (1810-93), and then Charles Van der Stappen. He finished his training in Paris in the 1880 os, obtained the Prix de Rome in 1882 and exhibited regularly in Paris as well as in Belgium. From 1878 onwards he turned to social realism, slightly preceding Meunier, but in a more conventional style. He also participated with realist labourers in the sculptural decoration projects

of the Petit Sablon and the Botanic Garden, led by Meunier and Van der Stappen. Before the war he had already finished several monuments throughout the country, some with plinths by Victor Horta. H. Lettens, 'De beeldhouwkunst tussen 1865 en 1895', in J. Van Lennep (ed.), De 19de-eeuwse Beeldhouwkunst, Brussels, Generale Bank, 199o, p. 107; S. le Bailly de Tilleghem in Van Lennep, as at note 27, pp. 321-23.

50. 'En Belgique', L'Echo Belge. Journal quotidien du matin paraissant à Amsterdam, 1 December 1916; 'Nos monuments', Le Belge Indépendant, 27 January 1919; Bulletin Communal de Saint-Josse-ten-Noode, 5 November 1915, 15 December 1915, 30 July 1919. In 1904 Charlier inherited the fortune of his friend Henri Van Cutsem which explains his financial security. Le Bailly de Tilleghem, as at note 49 , pp. 322-23. The authors would like to thank Michel Delabaye, author of 'Autour et alentour d'une maison communale centenaire 1911-2011' (brochure published by 'Les Amis du Square Armand Steurs' in 2011), for sharing his archival sources on the Charlier monument.

51. 'Sur la Grand'Place, la " Brabançonne " surgit radieuse, heureuse de pourvoir faire enfin retenir les accents si longtemps réprimés. «Le Belge sort du tombeau ": ah! oui! Il en sort la tête haute, la face sereine, comme celle de cette femme a quile sculpteur Samuel a communiqué toute son ardeur de patriote délivré.' La Gazette, 19 November 1918.

52. La Gazette, 19 November 1918 La presse de Bruxelles, 17 November 1918.

53. 'À Bruxelles. Les Anglais à Bruxelles', Le Belge Indépendant, 20 December 1918.

54. 'Nos sculpteurs pendant l'occupation boche ne sont donc pas restés inactifs et ils ont contribué à rendre la cité encore plus belle pendant ces jours de fête [...]' Le Belge Indépendant, 13 December 1918.

55. G.V., 'A Bruxelles', Le Belge Indépendant, 1 February 1919: 'Quelques-uns avaient de l'allure, une pensée généreuse, de belles lignes, je vous les ai décrits. Les autres ne répondent pas au symbole qu'il voulaient incarner. Ils manquaient de sentiment et d'âme. Il n'étaient pas que d'informes esquisses.' 
57. S. Pierron, La Sculpture en Belgique 1830-1930, Paris-BrusselsCourtrai, 1932.

58. Le Peuple, 4 December 1918

59. Le Peuple, 4 December 1918

('la négation de cette orientation moderniste').

6o. Le Peuple, 4 December 1918 ('tout en reconnaissant que certains artistes, dans leurs conceptions, ont obéi à ce sentiment démocratique qui doit un jour socialiser les beaux-arts')

61. Lettens, as at note 49 p. 107; R. Hoozee and F. Aubry (eds), Brussel, kruispunt van culturen, Antwerp, Mercatorfonds, 2000

62. B. Fornari, 'Academisme en omwentelingen rond de eeuwwisseling', in J. Van Lennep (ed.) as at note 49, pp. 119-46; G. Ollinger Zinque, Les $X X$, La Libre Esthétique: cent ans après, Brussels, Musées royaux de Beaux-Arts de Belgique, 1993.

63. P. Sanchez (ed.), Le Salon des " $X X$ " et de La Libre Esthétique. Répertoire des exposants et liste de leurs oeuvres. Bruxelles, 1884-1914, Dijon, L'Echelle de Jacob, 2012, passim.

64. J. Van Lennep, Catalogus van de beeldhouwkunst. Kunstenaars geboren tussen 1750 en 1882 , Brussels-Ghent, KMSKB, SnoeckDucaju en zoon, 1992, pp. 23-26; Sanchez (ed.), as at note 63; D. N. Prina, 'Beyaert's Square de la Place du Petit Sablon: architectural sculpture, identity, and artistic and politica networks in late nineteenth-century Brussels', Sculpture Journal, 25, 3 , 2016, pp. 329-42.

65. Van Lennep, as at note 64 p. 24; J. Van Lennep, 'Standbeelden en monumenten van Brussel vóór 1914', in P. Derom and G. Marquenie (eds), De beelden van Brussel,

Antwerp, Pandora, 200o, pp. 87-88.

66. Champal, 'La sculpture populaire', La Réforme, 1 July 1891 ; Van Lennep, as at note 65 , pp. $87-88$

67. E. Picard, 'La socialisation de l'art (1). Conférence de M. Edmond Picard', L'Art Moderne, 15, 14, 7 April 1895, p. 109; O. Maus, 'Sculptures de plein-air', L'Art Moderne, 20 August 1905, p. 271; O. Maus, 'Musées en plein-air', L'Art Moderne, 15 October 1911, p. 331; O. Maus, 'Rodin à Ixelles', L'Art Moderne, 24 September 1911, p. 306; Van Lennep, as at note 65 , p. 88 .

68. Maus, as at note 67 ('Rodin'); Fornari, as at note 62, p. 132 . The initiative was also defended in L'Art Moderne by, among others, Louis Dumont-Wilden, a leading Belgian journalist and art critic, and one of the founders of the Brussels satirical weekly Pourquoi Pas? which published lengthy articles on Samue en Wolfers in 1914. Van Lennep, as at note 65, p. 88 .

69. Maus, 'Rodin' and 'Musées', as at note 67; Van Lennep, as at note 65 , p. 88

70. This practice is clear from the salon catalogues, which feature many plaster models, often referring to a planned or desired state in durable materials. The city of Paris, for example, usually bought plaster models at the Salon, and then financed their conversion into stone or bronze for one of its collections or public spaces. See J. Hargrove, 'Les statues de Paris', in P. Nora (ed.), Les lieux de mémoire, Paris, Gallimard, 1986, pp. 243-82; A. Pingeot (ed.), La sculpture française au XIXe siècle, Paris, Grand Palais, 1986.

71. A famous example in this respect is the monumental Éléphant de La Bastille in Paris. See D. P. Jordan, Napoleon and the Revolution, Basingstoke, Palgrave Macmillan, 2012, p. 160; D. Rowell, Paris: The 'New Rome' of Napoleon I, London, Bloomsbury, 2012, pp. 66-67; W. H. Ireland, The Napoleon Anecdotes: Illustrating the mental energies of the late emperor of France; and the characters and actions of his contemporary statesmen and warriors, Printed for C. S. Arnold, 1823 , p. 50.

72. J. Wijnsouw and M. Sterckx "Een machtige veropenbaring der jeugdige Gentsche kunst”. Publieke kunst in het kader van de Gentse Wereldtentoonstelling van 1913', Handelingen der Maatschappij voor Geschiedenis en Oudheidkunde te Gent, 66, 2012, p. 24.

73. G. Verbeek, Virga Jesse, schat van de Hasselaar, Hasselt, Stad Hasselt, 1988.

74. J. Janssens, De Belgische natie viert: de Belgische nationale feesten, 1830-1914, Leuven, Leuven University Press, 2001.

75. L. Hymans, XXVe anniversaire de l'inauguration du roi. Les fêtes de juillet, compte rendu des solennités et cérémonies publiques célébrées à Bruxelles les 21, 22 et 23 juillet, Brussels, Alexandre Jamar, 1856; quoted in Janssens, as at note 74, p. 23 (our translation)

76. In Antwerp, for example, artists had been engaged to create ephemeral decorations for the festive entry of the Archduke Albrecht and Isabella in 1599, and of Archduke Ferdinand of Austria in 1634. For the latter occasion, among others, Pieter Paul Ruben created a statue of Mercurius leaving Antwerp for the Mercurius stage. I. R. Martin, The Decorations for the Pompa Introitus Ferdinandi, vol.

XVI, Corpus Rubenianum Ludwig Burchard, London, Phaidon, 1972, pp. 178-86.

77. For example, for the nationa festivities of 1856 , Guillaume Geefs contributed eight allegories of 'the most important virtues of the king and the nation' (each with a height of 3.5 metres): wisdom, unity, carefulness, independence, peace, progress, justice and power. Charles Van der Stappen's monument to Alexandre Gendebien, one of the founding fathers of the Belgian nation-state, was inaugurated in Brussels during the National September Festivities in 1874 commemorating the Belgian Revolution of 1830 .

78. Janssens, as at note 74 , pp. 23-39.

79. For example, citizens of working-class neighbourhood in London's East End marked the voluntary enlistment of 65 men of their neighbourhood with a street shrine. Their example was followed by several other neighbourhoods. In 1917 the queen visited the shrines in the area. J. Winter, Sites of Memory, Sites of Mourning. The Great War in European Cultural History, Cambridge, Cambridge University Press, 2003, p. 80.

8o. Before it was melted down, the existence of the memorial was documented by press photos, picture postcards and a Messter Woche newsreel item (1915, no. 8).

81. We are referring to the official Tannenberg memorial built in Hohenstein/Olsztynek in 1924-27 by the Berlin architects Johannes and Walter Krüger

82. A photograph of the inauguration appeared in The Daily Mirror, 5 August 1918. The architect Edwin Lutyens was asked to design a monument to replace the temporary war shrine, but this project did not materialize. J. Geurst, Cemeteries of the Great War by Sir Edwin Lutyens, Rotterdam, 010 Publishers, 2010 pp. 51-53; A. King, Memorials of the Great War in Britain: The Symbolism and Politics of Remembrance, London, Berg Publishers, 1998, pp. 55-56.

83. See the cover of L'Illustration, 26 October 1918 . A contemporary reaction to the model can be found in H. P. Adam, Paris Sees it Through. A Diary, 1914-1919, London, Hodder and Stoughton, 1919, p. 251: 'A few days ago an enormous square erection of wood appeared outside the Grand Palais in the Champs Elysees. It looked like a big case on a gigantic scale and nobody could conceive what might be inside it. The mystery is now clear. The case has been opened, and within it is a plaster cast for a group. This is M. Francois Sicard's design for a symbolic group, "Au Poilu”. [...] At present the meaning of the group is all we care for, but in the course of time we may regret that our patriotism got the better of our critical faculty.'

84. Claisse, as at note 4, p. 31

85 . This is likely to have been the first temporary monument erected during the war in occupied Belgium. It was inaugurated on 1 November 1915. 'À Bruxelles', L'ami de l'ordre, 20 October 1915; 'À Bruxelles. Le jour des

morts', Le XXe siècle: journal d'union et d'action catholique, 11 November 1915

86. 'Le jour des morts à Bruxelles', Le XXe siècle: journal d'union et d'action catholique, 14 November 1916

87. Winter, as at note 79

pp. 86-9o.

88. 'Echos. À Ixelles', L'étoile belge, 23 December 1918. Another article refers to the same monument as Aux braves morts pour la Patrie 1914-1918. 'Une grande cérémonie patriotique à Ixelles', La dernière heure, 23 December 1918. De Rudder was a pupil of Simonis and provided

the Wolfers firm (he was a close collaborator to Philippe Wolfers) and the bronze foundry Luppens with 'hundreds' of utilitarian and ornamental designs. He also contributed two statues for the Brussels Botanical Garden sculpture project, worked in ivory, and exhibited with Pourl'Art. In the years after 1900 , De Rudder realized several funeral and meditative sculptures, such as Psyche, Grief, Mourning and Funerary figure. H. Lettens in Van Lennep, as at note 27, pp. 344-47.

89. The other three soldiers were made by Charles Samuel, Marcel Rau and Jules Herbays. Like De Rudder, they were all working in Ixelles. The bronzes were cast at three different foundries. Vandervelde, as at note 35 , pp. 320-22; Derom, Marquenie and Everarts, as at note 15, p. 94 .

90. On 14 July 1919 a resolution was adopted confirming the intention to build a great national war memorial in Brussels. In the following years several locations and artists were proposed, but no consensus was reached. Eventually, the state settled for a burial of the great Unknown in 1922 at the foot of the Congress Column in Brussels. The latter was built in the 1850 s to commemorate the founding of Belgium and the Belgian Constitution in 1830. In 1924 this grave was completed with an eternal flame and the project to build a new national war memorial was abandoned altogether. Claisse, as at note 4 ; Claisse, as at note 3 .

91. Claisse, as at note 4, pp. 62-63.

92. This location was used for temporary monuments on several occasions. In 1885 , for example, a catafalque for Victor Hugo (by Alexandre Falguière, and with 
96. 'Une suggestion', Le Soir, 8 December 1918 ('mais on pourrait en distinguer un entre les meilleurs, et l'élever par souscription publique').

97. Le Soir, 1980, as at note 14 ; letter from the city architect of Brussels to an alderman, 8 January 1919, Brussels City Archives, A, D8, nr. 71; as mentioned by C. Leclercq, 'Standbeelden en monumenten van Brussel na 1914', in Derom and Marquenie (eds), as at note 65 .

98. J. Ogonovsky in Van Lennep, as at note 27, p. 551; Derom, Marquenie and Everarts, as at note 15, p. 97, no. 12-34.

99. With appropriate display, the statue was inaugurated on 16 November 1930. For a concise history of the monument, see Leclercq, as at note 97, pp 207-09.

100. 'ô Belgique, ô mère chérie, À toi nos cœurs, à toi nos bras, À toi notre sang, ô Patrie! Nous le jurons tous, tu vivras!' Initially there was only a French version of the anthem. In 1938 an official Flemish translation was accepted. This text was added to the plinth of La Brabançonne later on.

101. Le Belge Indépendant, 27 January 1919.

102. La Fédération Artistique, 1903, p. 112; La Réforme, 1903; G. Des Marez, Guide illustrée de Bruxelles. Monuments civils et religieux, Brussels, 1958, p. 337; Van Lennep, as at note 65, pp 125-26; Derom, Marquenie and Everarts, as at note 15 , cat. 18-4; B. Mihail, 'Dossier: Monumenten voor de doden en de helden van het vaderland. Het herinneringserfgoed van de twee wereldoorlogen in Brussel', Erfgoed Brussel, 011-012, 2014, p. 80. The monument was cast by the Brussels foundry Verbeyst, as were most of the later Brussels war memorials. Postcards of Charlier's war memorial were immediately made and sent. Also another monumental statue by Charlier, The Stonemasons, would shortly afterwards find a permanent place in the same municipality, in the same Steurs square.

103. The next war memorials in Brussels were only inaugurated in autumn 1921. As derived from Derom, Marquenie and Everarts, as at note 15 . After the Second World War Charlier's monument was moved to the nearby Rue du Méridien, where it still stands today.

104. Ghent, 1937; Nieuport, 1938; Brussels, 1951, Namur, 1954; Bruges, 1954; Liège, 1964.

105. Le Belge Indépendant, 1 February 1919; 'Het graf van Miss Cavell', Belgisch dagblad, 5 December 1918; 'Pour aller à Bruxelles', Le Belge indépendant, 6 December 1918.

106. Le Petit Journal, 22 November 1918, p. 1.
107. 'De tous ces monuments, un seul, paraît-il, sera destiné à survivre, celui de miss Edith Cavell, de Morin.' Le Belge Indépendant, 1 February 1919. 108. Le Belge Indépendant, 20 December 1918.

109. Engelen and Sterckx, as at note 36 .

110. Y. Randaxhe, 'Sculpter, construire: monument et sculpture publique au XXième siècle', in J. Stiennon (ed.), L'architecture, la sculpture et l'art des jardins à Bruxelles et en Wallonie, Brussels, De Boeck, 1995, pp. 254-64; Van Lennep, as at note 65 , p. 144 . 111. Mihail, as at note 102 , pp. 79-8o.

112. Derom, Marquenie and Everarts, as at note 15, p. 106. 113. Leclercq, as at note 97, p. 185 
Copyright of Sculpture Journal is published by Liverpool University Press, and its content may not be copied or emailed to multiple sites or posted to a listserv without Liverpool University Press's express written copyright permission. However, users may print, download, or email articles for individual use. 